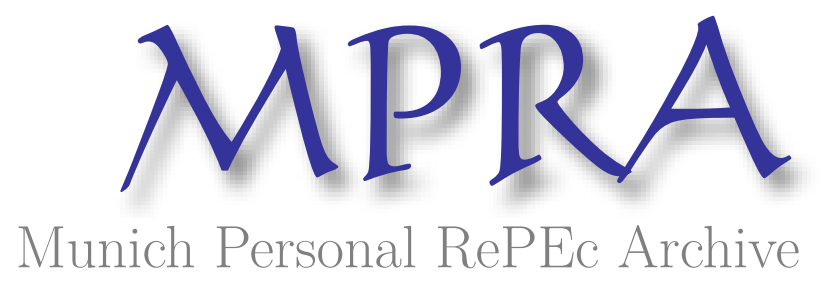

\title{
Financial Inclusion and Economic Growth: The Role of Governance in Selected MENA Countries
}

Emara, Noha and El Said, Ayah

Rutgers University, City University London

17 October 2019

Online at https://mpra.ub.uni-muenchen.de/99257/

MPRA Paper No. 99257, posted 27 Mar 2020 07:51 UTC 


\section{Financial Inclusion and Economic Growth: The Role of Governance in Selected MENA Countries}

Noha Emara, Ph.D. (Corresponding Author)

Department of Economics

Rutgers University, the State University of New Jersey

311 North 5th Street

Camden, NJ 08102, USA

Tel: 856/225-6765

E-mail: nemara@,camden.rutgers.edu

Ayah El Said, Ph.D.

Department of Economics

City University of London

E-mail: ayah.el-said.1@,city.ac.uk

JEL Classification Numbers: C23; G21; O43

Keywords: Financial Inclusion; Governance; Economic Growth; MENA; Financial Development 


\begin{abstract}
Financial inclusion, whether in terms of adoption or usage, is one of the main, but challenging priorities in the MENA region. The paper empirically investigates the relationship between financial inclusion and economic growth in selected MENA countries. A system GMM dynamic panel model technique is employed on yearly data for the period 1965-2016, using a number of measures of financial inclusion covering the households and the firms access to finance. Particularly, the study uses indicators such as the number of bank accounts (per 1000 adult population), bank accounts for corporates/enterprises, and the number of bank branches and ATMS (per 100,000 people), percentage of firms using banks to finance investments, the percentage of firms using bank loans to finance working capital, and the percentage of firms using banks to finance investments. The results of the study indicate that financial inclusion positively impacts GDP per capita growth in the selected countries. Financial inclusion measured by the household's financial access index has a positive and statistically significant impact on economic growth in the MENA region, but requires supervisory and regulatory regimes with backing of the rule of law, judicial independence, contract enforcement, control of corruption, and political stability. The effect firms' access to finance is only significant in the presence of strong institutions. The results were insignificant for the general financial inclusion measure.
\end{abstract}




\section{Introduction}

In a world where information is far from perfect, information and transaction costs become the rule. If such costs become sufficiently expensive, some transactions may not wholly take place (Khan and Senhadji, 2003). Consequently, the rise of financial intermediaries was inevitable to make such transactions plausible, loosen financial frictions, in addition to ameliorating any associated costs and market imperfections.

Simply put, financial intermediaries are institutions that channel savings to investors, thereby, increasing access to capital to concerned stakeholders. The rise of the aforementioned intermediaries has been a cornerstone in the process of financial development for any economy. As Levine (2005) put it, financial development broadly takes place when financial instruments, markets, and intermediaries improve the impact of information, enforcement, and transactions costs. Such improvements allow financial intermediaries to efficiently allocate resources, aid the process of exchanging, hedging, diversifying, and pooling of risk; mobilize and pool savings, evaluate investments, exercise corporate control and governance, as well as assist in the process of exchanging goods and services.

Financial development is important in terms of its impact on economic growth. The link between financial development and economic growth can be traced as far as Schumpeter (1912)' more recently McKinnon (1973) and Shaw (1973), and is well established by now in terms of empirical evidence ${ }^{2}$.

In addition, given the different pillars of the financial development that range from banking, to equity, to bonds, to insurance, only a handful of studies attempted to investigate whether they affected economic growth differently ${ }^{3}$. Hence, breaking up the different types of financial development permits the investigation of how economic growth is affected by the different types of financial development.

Thus, the purpose of this study is to examine the effects of financial development, and more specifically financial access, for a group of Emerging Markets (EMs) and Middle East

\footnotetext{
${ }^{1}$ Schumpeter held that financial intermediaries select the firms that utilize an economy's savings. More formally, his view stipulated that financial intermediaries tend to adjust the process of savings allocation rather than alter the savings rate itself. Thus, Schumpeter's notion of finance and development focuses on the effect of financial intermediaries on productivity growth and the rates of technological change. Beck at al. (2000). Finance and the sources of growth.

${ }^{2}$ For a detailed review of the literature on finance and growth, see Levine (2005).

${ }^{3}$ Chin and Ito (2007) attempted a similar examination of the impact of different types of financial development on the current account rather than on savings, acknowledging the ambiguity of the relation with regards to savings.
} 
and Africa (MENA) Region, where the latter is a region characterized by low financial access.

Financial inclusion - access to, and use of, financial products and services by households or firms - is one of the main, albeit challenging priorities in Emerging Markets (EMs), and a key factor for financial development ${ }^{4}$. Regional blocs ${ }^{5}$ and international financial organizations, including the World Bank, the International Monetary Fund, the Asian Development Bank, and the African Development Bank, are among the many entities currently prioritizing access to finance. Financial inclusion units, both within Central Banks, and Finance Ministries, have been on the rise, and bolstering access to finance has become an issue that has been repeatedly addressed in various G-20 statements (see Beck, 2016)). ${ }_{-}$Over the last decade, the global average of ATMs per 100,000 adults has increased by at least two thirds, ${ }^{7}$ while the global average of holders - especially for depositing purposes - has more than doubled (IMF, 2018), as shown in Figure (1).

\section{Figure (1): Evolution in Financial Inclusion Trends Over the Last Decade}

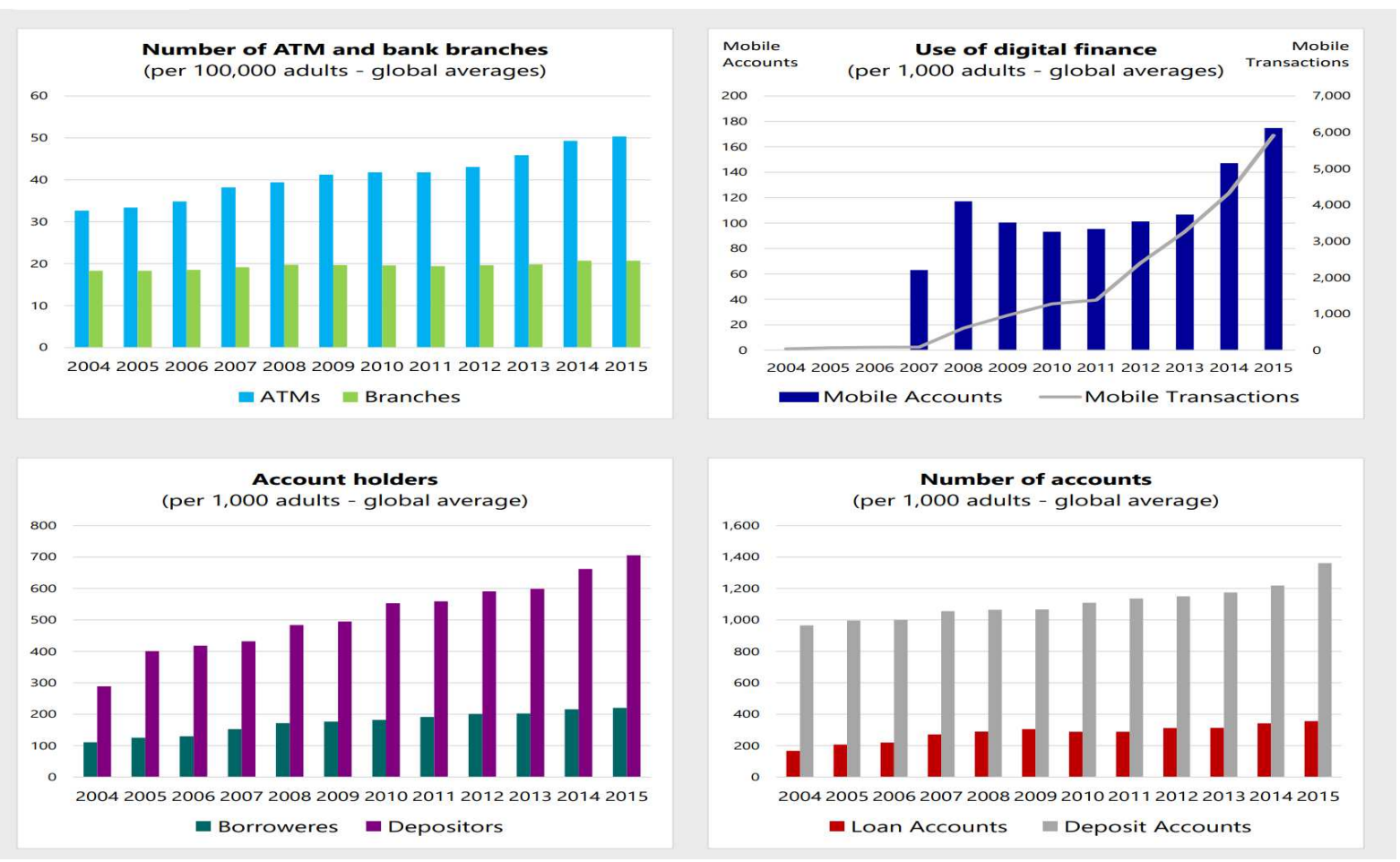

Source: IMF Financial Access Survey (via IMF, 2018)

\footnotetext{
${ }^{4}$ The literature on financial inclusion over the last decade established that financial development goes well beyond economic growth (see for example Beck, 2016), Levine, 2005, and Beck, 2009), with financial development contributing to improved income distribution, and reduced poverty (Beck, 2016), even if financial inclusion was lagging ${ }^{5}$ G20, APEC, ASEAN, and GCC.

${ }^{6}$ Yet, still over half of the central banks globally have no financial inclusion mandate, but rather objectives related to financial inclusion (Tissot and Gadanecz, 2017).

${ }^{7}$ From 30 in 2004, to almost 50 in 2015.
} 
Financial inclusion is of key importance, particularly to EMs and frontier markets whose levels of financial development, as well as access to finance, are well below those of advanced economies. Financial inclusion can thus help consumption smoothing with significant welfare gains (see, for example, Jappelli and Pagano, 1989; Bacchetta and Gerlach, 1997; Ludvigson, 1999), and help in lowering income inequality by increasing the income of the poorest quintile (Beck et al., 2007), thus boosting savings (Dupas and Robinson, 2013). Moreover, it can act as a lever to reduce the significant rise in extreme global inequality (IMF, 2018), while playing a crucial part in risk diversification and building trust in the financial system, (Cihak et Al., 2016), something that EM and frontier economies lack. Its contribution, therefore, when it comes to growth (IMF, 2016), as well as in terms of alleviating poverty and inequality, cannot be ignored. Ideally, financial inclusion should ensure the sufficient provision of financial services to households, corporates, and governments, in order to improve individual (and overall) welfare (Beck, 2016), without jeopardizing financial stability.

Access to finance in the MENA region has been limited. Specifically, the MENA region is one that can be characterized by the following; 1) it lacks financial deepening; 2) its financial markets are underdeveloped; 3) its financial markets are bank based rather than market based; 3) it has insufficient collateral; 4) has limited secured transactions; 4) and has limited access to finance. This is especially the case among the region's oil importance. In fact, financial inclusion has been rising as a priority across the MENA region, and has significant growth opportunities. The regional turmoil across the MENA region has hit the oil importers the most, leading to more risk aversion, subdued credit growth, lower liquidity, whereby external support acting as a buffer against such uncertainty, with significant stock market volatilities in some countries. However, the region's banks generally are well capitalized.

As previously mentioned, bank-based financial institutions dominate the MENA region's financial sector, while public banks dominate, once again among oil importers. The relative inefficiencies in state-owned enterprises have been linked to poorer bank credit, and lower banking sector profitability. Overall, private sector credit is low relative to other Emerging Markets, once again, especially among the region's oil importers. 
Figures (1 \& 2): Bank Credit Lower Among the MENA Region's Oil Importers
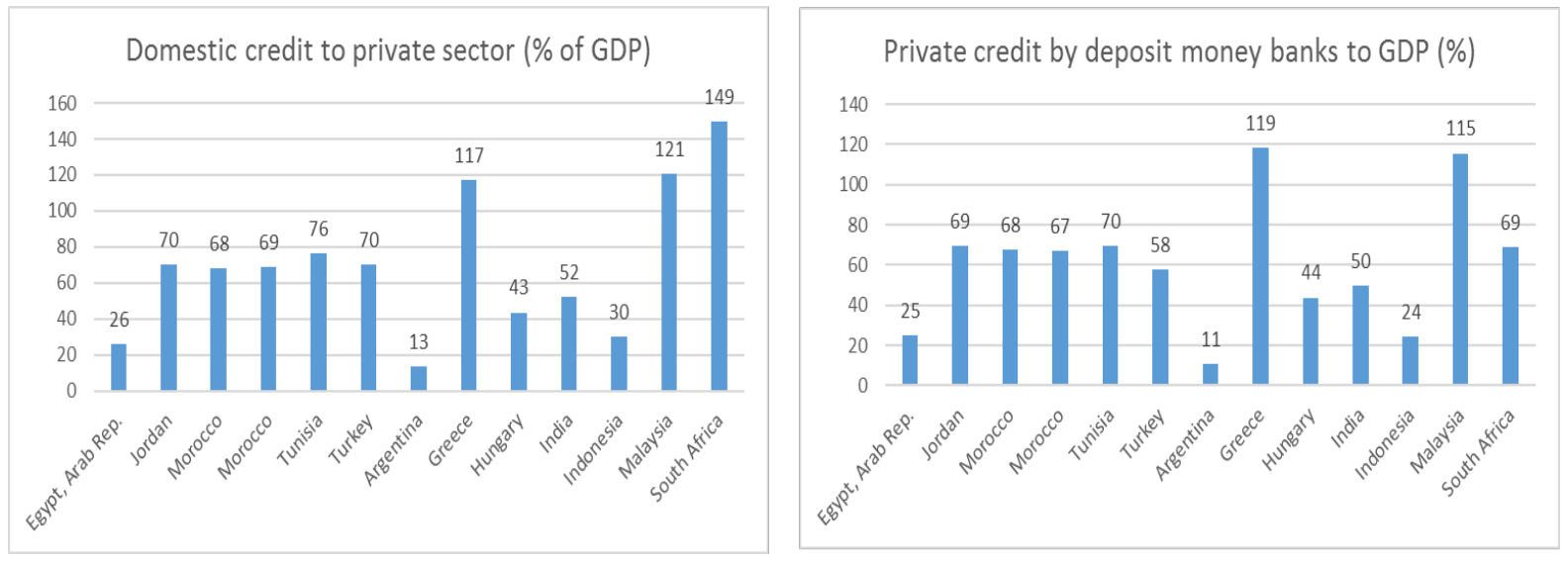

Source: World Bank Global Financial Development Database (2016; both charts)

On the non-bank side, there is significant scope for non-bank financial development especially as the stock market capitalization significantly improved. This has been due to reforms, incentives to list in stock exchanges, and opening up to foreign investor. This has led to a larger stock market size. Yet stock market liquidity (value traded), remains low, exacerbated by regional turmoil

Figures (3 \&4): Low Stock and Bond Market Development in Selected MENA Countries

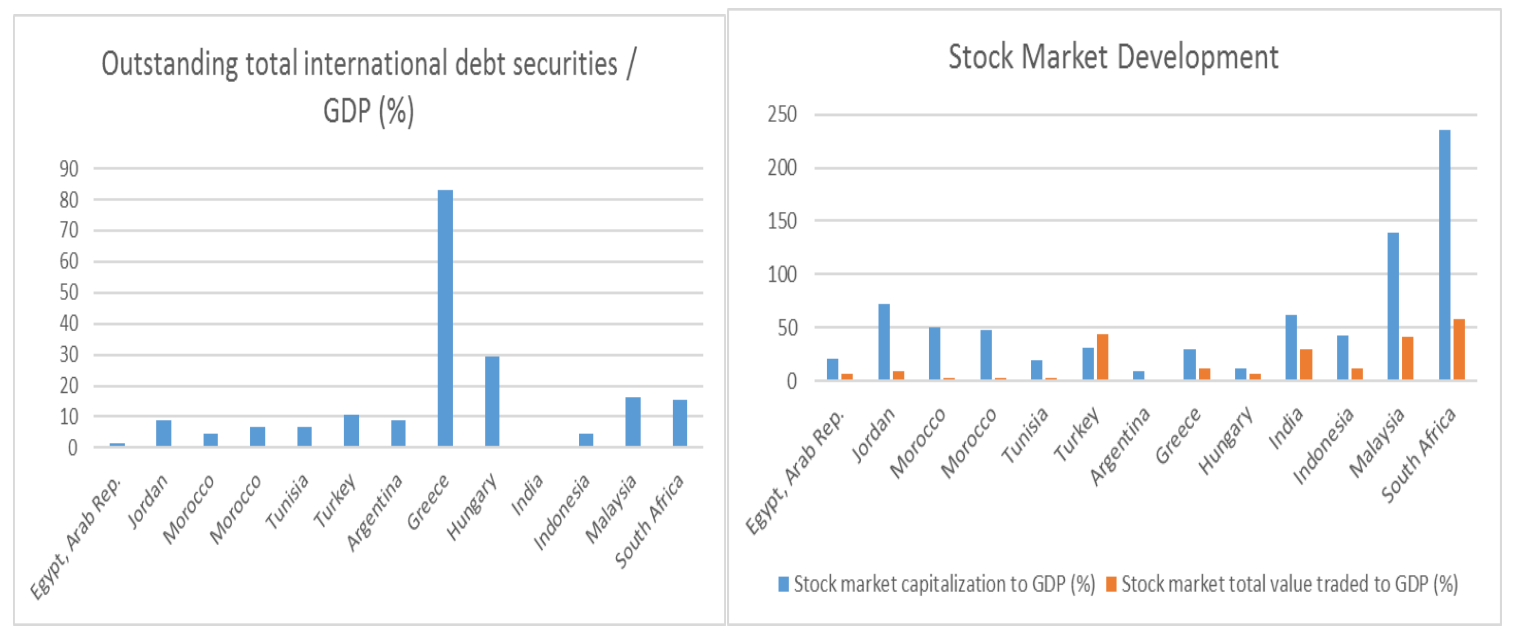

Source: World Bank Global Financial Development Database (2016; both charts)

Overall, the MENA region suffers from a small presence of non-bank financial institutions; small insurance sector, limited private equity, hedge fund, pension funds activity, perhaps with the exception of Morocco, whereby insurance is mandatory and is used by $24 \%$ of the adult population in Morocco. 
Figure (5): Low Insurance in Selected MENA Countries

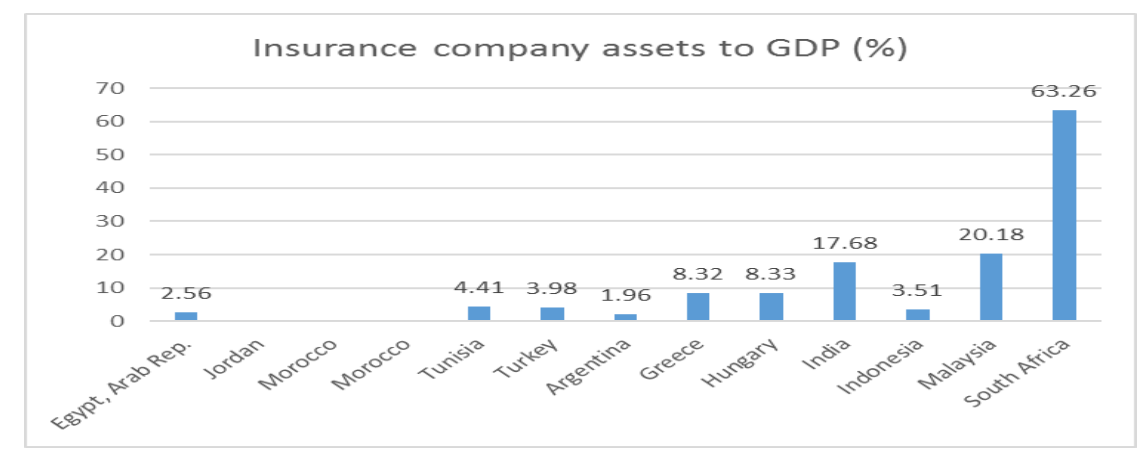

Source: World Bank Global Financial Development Database (2016; both charts)

As to access to finance, the MENA region has a low financial penetration whereby Egypt and Morocco have the least access to finance/bank financing, and small firms are more constrained in their ability to access financing via formal means. Access to finance is recognized as a major constraint relative to neighbouring Turkey and other Emerging Markets. Almost $50 \%$ of adult population in among the bigger oil importers (Jordan, Morocco, Tunisia and Egypt) are underserved by the banking system, leaving scope to resort to informal means of credit/saving.

Figures (6,7 \&8): Low Financial Penetration Across Selected MENA (oil importing) countries

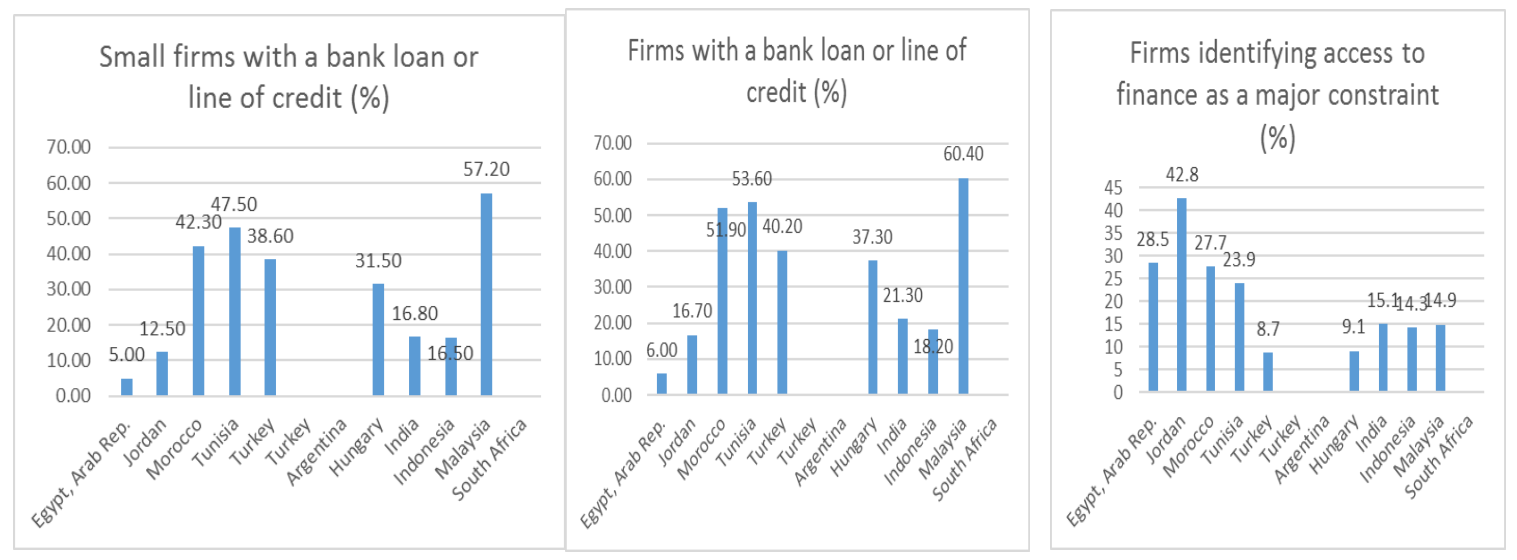

Source: World Bank Global Financial Development Database (2016)

The region also grapples with a high concentration ratio, which contributes to the limited access to finance. In fact, the MENA region is home to some of the world's highest bank/loan 
concentration ratios, which leads to a bias towards lending to large firms and excluding young/small firms.

Figure (9): Bank Concentration Ratios in Selected Oil Importers: Among the World's Highest

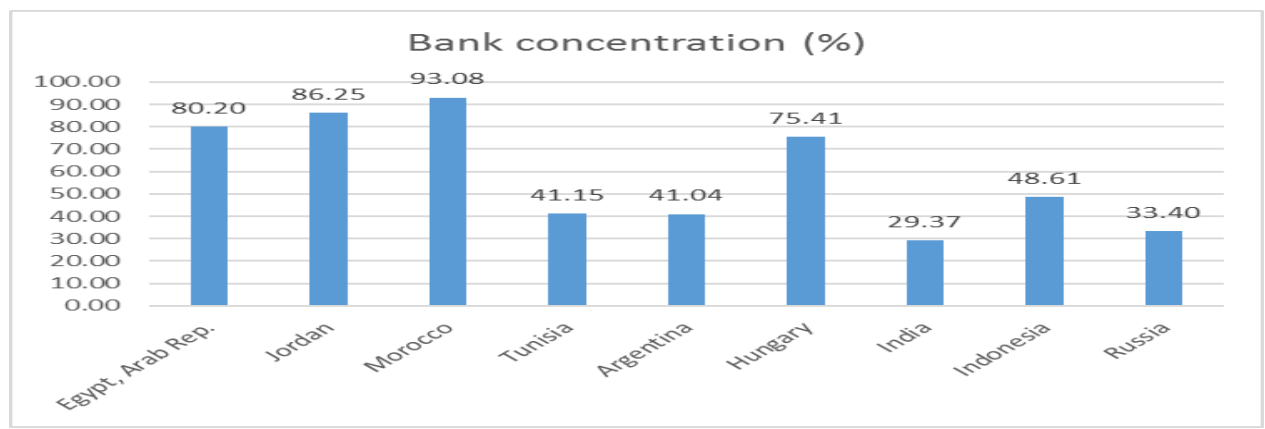

Source: World Bank Global Financial Development Database (2016)

There is also a low share of adults with an account at a formal financial Institution; Morocco stands out above the $28 \%$ average of lower middle-income countries There is also an even lower share of women with an account at a formal financial institution.

\section{Figure (10): Share of Adults and Women at a Formal Financial Institution}
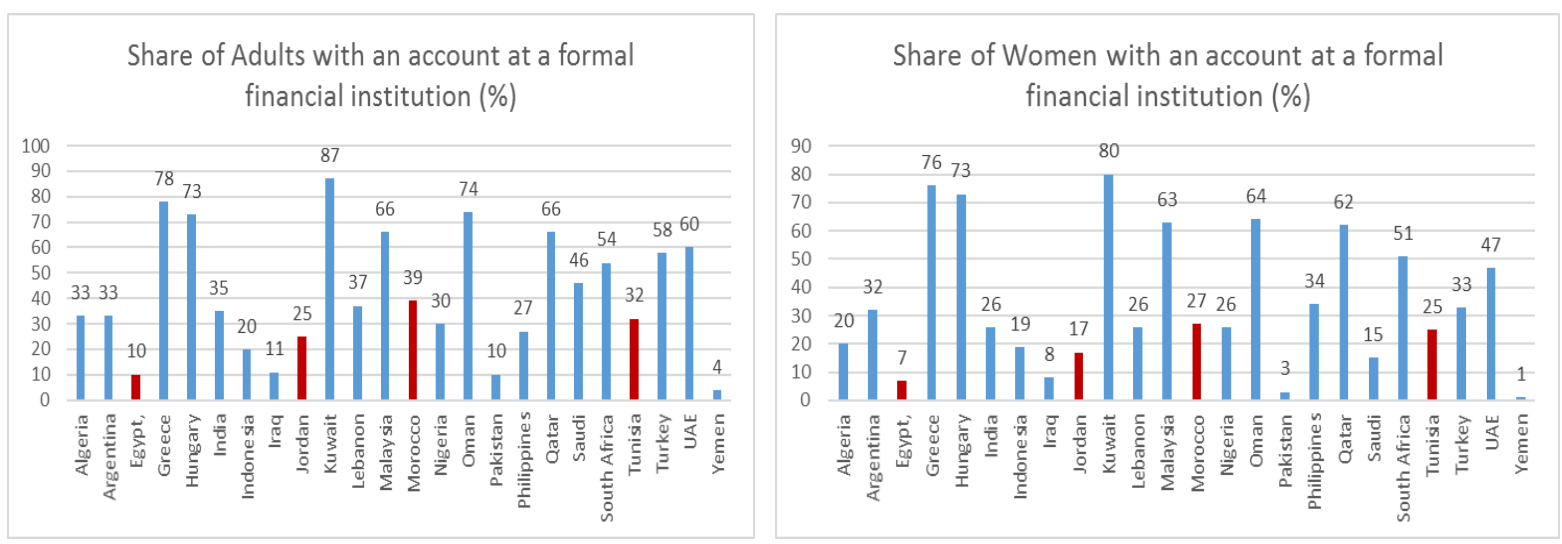

Source: World Bank Global Financial Development Database (2016)

Despite the regional turmoil, and the underdevelopment of some of the MENA region's countries, the region's financial sector continues to be sound. The region's banks are generally well capitalized, with NPLs relatively contained despite some increases in Morocco and Tunisia. Reforms are in place to bring them back to a "tolerable" level in Tunisia. 
However, higher provisions across the region's oil importers (97\% in Egypt vs. $60 \%$ in Tunisia) imply subdued credit growth. Given Egypt's weak macroeconomic environment, there is a higher level of dollarization, in addition to Jordan, but an improvement is expected. There is also scope for macroprudential policies to support financial stability.

Given the importance of financial access on economic growth, this study will attempt to answer several questions; do different types of financial access indicators affect economic growth? Is the effect the same across the two samples, EMs and MENA? How does the level of institutional quality influence the effectiveness of financial access measures on economic growth? The rest of this paper will be divided as follows. Section II will briefly review the literature, Section III describes the data used, Section IV will highlight the methodology employed and the model specification, Section V will highlight our results, and Section VI will conclude. The appendix is by the end of the paper.

\section{Literature Review}

There is a vast amount of literature on the determinants and impact of financial development, the link between financial development and growth. ${ }^{8}$ However, the literature that examines the role of financial access in the MENA region and the possible impact of institutional quality on financial access link to growth is not as vast. Hence, we briefly outline the most commonly cited literature on the above strands, followed by a detailed account of the studies that combines them.

Gerschenkron (1962) in addition to others, assert that banks finance growth in a more effective and efficient way relative to market-based systems, particularly in under-developed economies. Levine (2002) added that advocates of bank-based systems argue that banks that are unimpeded by regulatory restrictions tend to benefit from economies of scale in the process of collecting information, and can, thus, enhance industrial growth. The difficulty of capturing financial development by one variable, or even in a single broad category was ascertained by Ito and Chinn (2007). Consequently, the existence of different types of financial development ranging from banks, bonds, equity, and insurance markets ${ }^{9}$ must be accounted for.

\footnotetext{
${ }^{8}$ For a detailed survey on the literature on the relation between financial development and growth, see Levine (1997, 1999a).

${ }^{9}$ Comprising the market-based system.
} 
Empirical studies testing the impact of financial development generally involved the use of cross-country studies to understand the relation between financial development and growth. The main findings of those papers held that cross-country differences in the levels of financial development explained a considerable fraction of the cross-country differences in growth rates (Khan and Senhadji, 2003). For a cross-section of 159 countries averaged over the period 1960-1999, the authors find that financial development has a positive impact on economic growth. King and Levine (1993) employed four measures of financial development ${ }^{10}$ reflecting the size and depth of the financial sector in a cross section of 80 countries averaged over the period 1960-1989. And authors found that the proxies employed were strongly linked to real per capita GDP growth, and the rate of capital accumulation ${ }^{11}$.

Many papers have studied the determinants of economic growth in the MENA region, for instance the study by Makdisi, Fattah, and Lima (2005) found that economic growth in the MENA region is statistically significantly affected by investment and the initial level of income. Nabli (2007) concludes that human capital and physical infrastructure are vital determinants of economic growth for MENA, as well as macroeconomic and external stability. More specifically the study found that better primary education, improved infrastructure networks, as well as health status of the people are the most important factors affecting economic growth in MENA. The study by Duncan, and Denaux (2013) found that initial income and openness, have a negative impact on economic growth, while being an oil producer has a positive impact on growth.

To examine the link between financial sector development and economic growth, using a Generalized Method of Moments (GMM) approach, Ayadi et. Al. (2013) used a sample of northern and southern Mediterranean countries over the period 1985-2009. They found that credit to the private sector and bank deposits are inversely linked to growth. The authors found that stock market size and liquidity is important for growth, especially institutional quality is taken into consideration.

Also using GMM, Hamdi and Hakimi (2015) study the effect of bank and stock markets developments on economic growth for eleven MENA countries over the period 1995 to 2010. The authors find a positive relationship between banking and financial developments

\footnotetext{
${ }^{10}$ The ratio of liquid liabilities of banks and non-bank institutions to GDP,${ }^{10}$ bank credit as a share of the sum of bank and central bank credit, the ratio of private credit to domestic credit, and private credit to GDP.

${ }^{11}$ A similar conclusion was made by Beck et. al (2000) upon employing a cross-country instrumental variable estimator to extort the exogenous constituent of financial intermediary development. Using data for 63 countries averaged over the period 1960-1995, a strong, positive connection was found between financial intermediary development and real per capita GDP growth. Such a connection translates into higher GDP growth as well as long-run links between financial intermediary development and physical capital growth.
} 
and economic growth. They highlighted the fact that stock markets in MENA countries are still underdevelopment, with a significant need for reforms to attract investors.

Using GMM estimation methodology for a panel sample of 74 countries over the period 1960 to 1995, Rioja and Valev (2003) found a statistically significant positive impact of financial development on economic growth. But, the relationship between finance and growth maybe uncertain in countries with low financial inclusion- and low financial development such as the case of the MENA region. Similarly, using panel data for a sample of 144 countries over the period 1985 to 2009, Abdmoulah and Jelili (2013) found a nonlinear relationship between economic growth and financial development as defined by the access to finance and density of commercial bank branches.

In terms of the role of institutional quality, among the first studies to address the question of financial inclusion beyond the greater scope of financial development was that of Beck et al. (2007b). Using data for banking sector outreach ${ }^{12}$ for 99 countries over the period 2003-2004, they found that institutional quality affects financial inclusion positively, while the degree of government ownership of banks has a negative effect. ${ }^{13}$ Other determinants of financial inclusion include GDP per capita, governance, and the institutional quality and the regulatory environment. (Rojas-Suarez, 2010, Park and Mercado, 2015, and Allen et al., 2016,).

Honohan (2008) uses financial access data for 160 countries within an OLS context and finds that increased mobile phone penetration ${ }^{14}$ and better institutional quality (as well as governance) are positively correlated with their access variables - the number of bank accounts per 100,000 adults - even when per capita income is controlled for. Similarily, Honohan and King (2009) finds that the availability of mobile phone increases household financial penetration ratios. On a more general context, the study of Sarma and Pais (2011) finds a strong correlation between economic development and financial inclusion are highly correlated. This result implies that the higher the level of development the fewer unbanked households ${ }^{15}$ are to be expected.

\footnotetext{
${ }^{12}$ Covering both access and use of financial services indicators.

${ }^{13}$ However, Demirguc-Kunt et al. (2015) highlight the importance of governments in encouraging financial inclusion, by transforming government payments from cash into bank (and ever more recently into mobile) accounts.

${ }^{14}$ Related to this is the rising literature on the role of digital payments in raising income and promoting financial inclusion. For more information, see Beck (2016).

${ }^{15}$ Or more financial inclusion, and less financial exclusion.
} 
The study by Cherif and Dreger (2014) analyzed the institutional determinants for financial development in the MENA. Corruption was the most important institutional factor for banking sector, while the impact of corruption and law and order appear to be relevant for the stock market. The authors concluded that more prompt economic integration is crucial for financial development, and is a pre-requisite for higher GDP growth.

Using data for 15 MENA countries over the period 1996-2010, Abouzayed and Fayoumi (2016) examined the relationship between economic growth and banking sector concentration with a particular focus on the role of institutional quality. They find a positive and significant relationship between economic growth and banking concentration as well as institutional quality. The authors concluded that banking concentration and institutional quality mattered for growth in MENA countries, while the interaction between concentration and institutional quality yielded a negative and significant result.

Additionally, Hall and Jones (1999) found a statistically significant effect of the improvement in institutions and effective government policies on capital accumulation, productivity, and, output per worker. Banerji and Humphreys (2003) concluded that good governance in the MENA region, is crucial to boosting growth. Using cross sectional sample of 150 countries, Kaufmann, Kraay and Zoido-Lobaton (1999) show a statistically significant correlation between governance and development. Similarly, Honohan (2008), Rojas-Suarez and Gonzales (2010), and Park and Mercado (2015) found a positive link between improvement in institutions and financial inclusion.

The study by Banerji and Humphreys (2003) on the MENA region shows that good governance - responsive, transparent, and accountable public institutions- is key to boosting growth and lowering poverty. Within the same lines, Kandil (2009) concluded that an improvement in institutional quality- corruption, regulatory quality, government effectiveness, and the rule of law) all have positive impact on GDP growth. Additionally, the study found that export growth is positively affected by political stability and rule of law, while worsening institutional quality may helped in the increase in loan financing and private investment in the MENA region.

Emara and Jhonsa (2014) concluded that the improvement in governance; lower corruption levels, better rule of law, increased political stability, lower internal violence, and more accountable governments are important for economic growth. Similarly, Emara and 
Chiu, (2016) found that an improvement in a composite governance indicator improves per capita GDP growth in the MENA region.

Against the above background it can be noticed that the literature on the link between financial inclusion and governance is very thin. Most research focuses on financial development, but financial inclusion has not been barely looked at. The study by Rajan and Zingales (2003) showed that changes in political structure are prerequisite for financial, and that inadequate financial competition is a consequence of political instability. Similarly, the study by Demetriades and Hook Law (2006) concluded strong institutional framework in which the financial system operates increases the positive impact of financial development on GDP per capita.

Chauvet and Jacolin (2017) showed that lack of financial inclusion coupled with low institutional quality and information asymmetries has a negative impact on financial development (that is, economic growth). More specifically, the study shows that low financial inclusion leads to a crowding out effect in favour of the government of a small number of firms or a reversal of the expected positive impact of financial development on economic growth.

Law and Habibullah (2006), Balach and Law (2015) concluded that strong institutional quality improves financial development and economic growth. Within the same lines, Law and Habibullah (2009) found that income and the quality of a country's institutions are the most important factors affecting the banking sector and capital markets. Similarly, the study by Law and Kutan (2018) concluded that the quality of institutions is crucial in mediating the positive relationship between banking sector development and economic growth.

\section{DATA}

The data set is constructed as a panel of country observations from the World Development Indicators of the World Bank's database. The data set includes 44 EMs and MENA countries over the period 1960-2015. The list of countries included in the sample is reported in Tables 1 and 2 of the appendix.

The dependent variable in the model is the real per capital GDP growth rate and the set of independent variables consist of inflation rate, growth rate of gross capital formation, 
government spending (as a percent of GDP), openness, population growth, and different financial access ${ }^{16}$ indicators covering different dimensions such as general financial access, households' financial access, and firms' financial access. The list of economic, financial, and governance variables used in the study is reported in Tables 3 through 6 of the appendix.

\section{MODEL SPECIFICATION \& METHODOLOGY}

To perform such an analysis, the following dynamic panel regression methodology is used:

$$
\begin{gathered}
G r_{i, t}=\alpha+\rho G r_{i, t-1}+\beta X_{i, t-1}+\delta F I_{i, t-1}+\varepsilon_{\mathrm{i}, \mathrm{t}} \\
i=1,2, \ldots \mathrm{N}, t=1960, \ldots \mathrm{T}
\end{gathered}
$$

Where $G r_{i t}$ denotes the growth of per capital real GDP, of country $i$, at time $t$. Next, $G r_{i t-1}$ is the lagged endogenous variable ${ }^{17}, X_{i t-l}$ is the vector of explanatory variables, $F I_{i t-1}$ represents financial inclusion indicators that covers different areas namely financial access of the financial system in country $i$ at time $t$, and $\varepsilon_{i t}$ is the error term.

To avoid the correlation problems, following Yafee (2003) Equation (1) is estimated using the General Method of Moments estimator (GMM) which consistently estimates the dynamic panel data model (Kitazawa (2003)). It is known in the literature that economic growth models are best estimated by dynamic panel system GMM (Caselli, Equivel and Lefort (1996) and Holtz-Eakin, Newey and Rosen (1988)) which is a methodology proposed by Arellano and Bover (1995), Blundell and Bond (1998), and Blundell, Bond, and Windmeijer (2000) to overcome the bias problems of the difference GMM methodology.

The system GMM combines together Equation (1) with Equation (2), which is simply the first difference of Equation (1) to eliminate the country specific or unobserved effect as suggested by Arellano and Bond (1991):

$$
\begin{gathered}
\left(G r_{i, t}-G r_{i, t-1}\right)=\alpha+\rho\left(G r_{i, t-1}-G r_{i, t-2}\right)+\beta\left(\mathrm{X}_{\mathrm{i}, \mathrm{t}-1}-\mathrm{X}_{\mathrm{i}, \mathrm{t}-2}\right)+\delta\left(\mathrm{FI}_{\mathrm{i}, \mathrm{t}-1}-\delta \mathrm{FI}_{\mathrm{i}, \mathrm{t}-2}\right) \\
+\left(\varepsilon_{\mathrm{i}, \mathrm{t}}-\varepsilon_{\mathrm{i}, \mathrm{t}-1}\right)
\end{gathered}
$$

As explained in details in Emara and El Said (2015), The System GMM assumes two extra assumptions over the Difference GMM. To ensure a zero correlation between the right hand

\footnotetext{
${ }^{16}$ Financial access and inclusion will be used interchangeably.

${ }^{17}$ Lagged values are included to account for causality.
} 
side variable and the list of regressors with the unobserved countries' fixed effects, two additional assumptions are added as follows,

$$
\begin{aligned}
E\left[\Delta G r_{i, t} \varepsilon_{i, t}\right] & =0, \text { For } t=2, \ldots, T \\
E\left[\Delta M_{i, t} \varepsilon_{i, t}\right] & =0, \text { For } t=2, \ldots, T
\end{aligned}
$$

where $M_{i, t}$ is the set of all the explanatory variables of Equation (1) or $X_{i, t}$ and $F I_{i, t}$.

Next, a dummy variable for the countries of the MENA is added to the model in order to estimate the impact of financial inclusion in the MENA region. The model explores how the changes in access to finance affect the changes in the growth of per capita real GDP in the MENA region v.s. other countries. To do so a dummy for MENA countries along with an interaction term is added to the model as follows,

$$
G r_{i, t}=\alpha+\rho G r_{i, t-1}+\beta X_{i, t-1}+\delta F I_{i, t-1}+\theta M E N A_{i, t}+\varphi\left(M E N A_{i} * F I_{i, t-1}\right)+\varepsilon_{i, t}
$$

where $M E N A_{i}$ represents the dummy variable, which takes 1 if country $i$ is a MENA country and zero if not. The total effect of the impact of the different areas of financial inclusion is estimated by adding the coefficient $\theta$ to the coefficient $\varphi$ and the statistical significance of the effect is estimated using the standard errors of these two coefficients.

Finally, to analyze if the availability of well-established and credible institutions can fully achieve the benefits of financial inclusion, an interaction term of the governance index is added to our model as follows.

$$
\begin{gathered}
G r_{i, t}=\alpha+\rho G r_{i, t-1}+\beta X_{i, t-1}+\delta F I_{i, t-1}+\theta M E N A_{i, t}+\varphi\left(M E N A_{i} * F I_{i, t-1} * G o v_{i, t}\right) \\
+\varepsilon_{i, t}
\end{gathered}
$$

Where $\operatorname{Gov}_{\mathrm{i}, \mathrm{t}}$ is the governance indicator index which is computed using the principal component analysis of six main areas including control of corruption, government effectiveness, political stability, regulatory quality, rule of law, and voice and accountability.

\section{ESTIMATION RESULTS}

In this section, we report the impact of the various financial inclusion measures - using different measures of access that can be grouped into general access measures, households' access measures, and firms' access measures - for our full sample, and for the MENA region 
to see how the levels of financial inclusion affect economic growth in this region as compared to the full sample. In addition, we interact governance with financial inclusion measures, to access the impact of regulatory and institutional quality on the effectiveness of financial inclusion measures as highlighted in several studies, including Beck et al. (2007b) and Honohan (2008) who found that the improvement in institutional quality increases financial inclusion.

To estimate the impact of financial access on economic growth we begin by highlighting our baseline regressions for the full sample, then we outline our results for the MENA region, and then we proceed to discuss the role of institutional quality, proxied by governance indicators in affecting the role of financial access on economic growth.

We start the analysis by using measures that capture access using variables that combine access to financial markets and financial institutions, as calculated by the IMF's Financial Development Database (Svirydzenka, 2016), as a broad measure of financial access reflecting access to bond and equity markets. The IMF's Financial Development Database includes bank branches and ATMs as their proxy for financial institutions access, while financial markets access is proxied by the percentage of market capitalization outside of the top-10 largest companies and the total number of issuers of debt.

Table (8) presents our baseline regression with economic growth as the dependent variable measured as the change in the log of real per capita GDP. It is regressed on its lag and different macroeconomic variables and the financial access indicators which capture the ability of both individuals and enterprises to access financial services. The results show that the main variables of the regression come with the expected sign and statistical significance with the exception of the government spending variable. Column 1 shows our baseline regression where economic growth is regressed on its lag, which as expected is positive and significant at the $1 \%$ level. The inflation rate displays a negative relationship, whereby a $1 \%$ increase in inflation rates lowers economic growth by $0.2 \%$. The investment rate shows a positive expected impact on economic growth where a $1 \%$ increase in fixed capital formation increases economic growth by about $0.1 \%$. The openness index displays a positive impact on economic growth with a magnitude of $0.01 \%$. Similarly, a $1 \%$ increase in population growth increases economic growth by $0.6 \%$. The index of Financial Institutions Acess (fia) is positive as expected and statistically significant, where a one unit increase in the fia index results in $0.032 \%$ increase in economic growth. 
Column 3 uses the other measure of financial inclusion, Financial Markets Access Index $(f m a)$, where again this index is calculated as the percent of market capitalization outside of top 10 largest companies and the total number of issuers of debt (as shown in Table (6)). The results suggest that a one unit increase in the fma index results in $0.011 \%$ increase in economic growth.

To combine the effects of both types of financial access, Column 5 shows the impact of a general financial access indicator (accgen), proxied by the principal component analysis of the two indices fia and fma. The results show that a one unit increase in the accgen index results in $0.023 \%$ increase in economic growth. Our results are in line with Gerschenkron (1962), King and Levine (1993), Levine (2001), Khan et. al (2013), and others who confirmed that financial development boosts economic growth.

In Columns 2, 4, and 6 the dummy variable for the MENA region is interacted with fma, fia, and accgen, respectively. The interaction terms are statically insignificant, however what matters is the total effect which are measured in Table (9) by adding the coefficient of the financial access indicator under consideration to its interaction term with the MENA dummy, as explained in Equation (4). Table (9) shows that the total effect of the impact of the fma, fia, and their combination represented by accgen are all statistically insignificant. This result confirms the fact that the MENA region suffers from financial underdevelopment, as evident by limited presence of non-bank financial institutions including a small insurance sector, limited private equity, hedge fund, and pension funds activity.

Table (10) shows the estimation results of Equation (5) where the effects of the different measures of financial inclusion on economic growth in the MENA region are estimated in the presence of improved institutional quality. In Columns 1, 2, and 3 the dummy variable for the MENA region is interacted with the governance index and with fma, fia, and accgen, respectively, and once again, the results are insignificant, highlighting the limited impact of financial inclusion on economic growth in the MENA region. Table (11) shows that the total effect of the impact of the fma, fia, and accgen, in the presence of good institutions are all statistically insignificant. This result implies that the improvement in the institutional quality in the MENA region does not affect the role of financial inclusion on economic growth, where inclusion is measured by the ability of both individuals and enterprises to access financial services. 
Table (12) introduces an alternative financial inclusion measure that reflects the households's access to financial services. This is comprised of ATMs per 100,000 adults $(\mathrm{atm})$, bank branches per 100,000 adults $(\mathrm{bb})$, and the number of depositors with commercial banks per 1,000 adults $(b a)$. Column 1 shows the results of the full sample for the first access indicator, ATMs machines, which has a statistically significant positive impact on economic growth, where a one unit increase in ATMs leads to an increase in economic growth by about $0.021 \%$. (how can we link the physical presence of ATM machines to economic growth?) Similarly, Column 3 shows that a one unit increase in bank accounts per 1000 adults leads to a statistically significant increase in economic growth by about $0.02 \%$. Column 5 shows that a one unit increase in bank branches per 1000 adults leads to a statistically significant increase in economic growth by about $0.003 \%$.

Next, to analyze the impact of household's access to finance on economic in the twenty-one MENA countries of our sample an interaction term of the dummy variable MENA is added to the regression. In Columns 2, 4, and 6 the dummy variable for the MENA region is interacted with $a t m, b a$, and $b b$, respectively. The interaction terms are statically insignificant, with the exception of the interaction term of $b b$. Next, Column 1 of Table (13) shows that the variable "acc", a linear combination using the principal component analysis of the three access to finance indicators, ATM machines, bank branches, and accounts, is positive and statistically significant where a one unit increase in acc leads to an increase in economic growth by about $0.007 \%$. Column 2 shows that the interaction term of the dummy for the MENA region with the acc indicator has positive statistically significant impact on economic growth.

Table (14) provides the calculations of the at the total effect of the availability of ATM machines, bank branches, accounts, and their linear combination on economic growth. The results show a positive statistically significant impact where a one unit increase in ATMs leads to about $0.015 \%$ increase in economic growth in the MENA region. The results also show that the total effect of the availability of bank branches in the MENA countries is positive and statistically significant where a one unit increase in bank branches leads to about $0.04 \%$ increase in economic growth. Similarly, the total effect of the availability of bank accounts is positive and statistically significant where a one unit increase in bank accounts leads to about $0.002 \%$ increase in economic growth. Finally, the total effect of the variable acc is statistically significant for the group of MENA countries, where a one unit increase in that variable results in about $0.004 \%$ increase in economic growth. 
To analyze how improved institutions can affect the role of households' access to finance on economic growth, Table (15) shows the dummy variable for the MENA region is interacted with the governance index and with $a t m, b b, b a$, and $a c c$, respectively whereby most of the results are insignificant. In contrast, Table (16) shows that the total effect of the impact of the atm, $b b, b a$, and $a c c$, in the presence of good institutions are all statistically significant, with the exception of the bank branches $(b b)$ variable. This result implies financial inclusion - conditional on improved institutional quality - positively affects economic growth in the MENA region, when inclusion is measured by the ability ATM machines and bank accounts. To dig deeper into how improved institutions can affect the role of households' access to finance on economic growth, Table (17) shows the results when the dummy variable for the MENA region is interacted with the six measures of the governance index with the $a c c$ indicator. More specifically, the results show a positive and statistically significant impact of the households' access to finance on economic growth conditional onimproved control of corruption, government effectiveness, political stability, regulatory quality, rule of law, and voice and accountability, where economic growth increases by $0.0076 \%, 0.0074 \%, 0.013 \%, 0.0079 \%, 0.0076 \%$, and $0.0070 \%$ respectively. These results are in line with Beck et al. (2007b), Honohan (2008), Cherif and Dreger (2016), and Park and Mercado (2015) who found that institutional quality increases financial inclusion. The results also support the findings of Banerji and Humphreys (2003), Emara and Johnsa (2014), and Emara and Chiu (2016) who found that an improvement in institutional quality improves economic growth in the MENA region.

Next, Table (18) introduces another financial inclusion measure that reflects the firms' access to financial services, comprised of the percentage of firms using banks to finance investments (finv), the percentage of firms using bank loans to finance working capital (fwork), and the percentage of firms identifying access to finance as a major constraint $(f c)$. Column (1) shows the results of the full sample for the first firm's access indicator, finv, which has a statistically significant positive impact on economic growth, where a one unit increase in finv leads to an increase in economic growth by about $0.073 \%$. Similarly, Column 3 shows that a one unit increase in fwork leads to a statistically significant increase in economic growth by about $0.069 \%$. However, Column 5 shows that a one unit increase in $f_{c}$ is statistically insignificantly affecting economic growth of the full sample.

Columns 2, 4, and 6 show the impact of firms's access to finance on economic growth in the MENA region where an interaction term of the dummy variable MENA is added to the 
regression. Again, the dummy variable for the MENA region is interacted with finv, fwork, and $f_{c}$, respectively, where results show that the three interaction terms are negative and statically significant. Column 1 of Table (19) shows the results for the full sample, where the variable "firmacc", which is computed as the principal component analysis of the three firms' access to finance indicators with finv, fwork, and $f c$, is positive and statistically significant where a one unit increase in firmacc leads to an increase in economic growth by about $0.08 \%$. Column 2 shows that the interaction term of the dummy for the MENA region with the firmacc indicator has a negative statistically significant impact on economic growth.

Table (20) provides the calculations of the at the total effect of the availability of with finv, fwork, and $f c$, and their linear combination, firmacc, on economic growth. The results show insignificant results with the exception of the variable the total effect of the variable $f_{c}$ which shows an expected statistically significant negative impact on economic growth in the MENA region, where a one percent increase in the percentage of firms identifying access to finance as a major constraint results in about $0.08 \%$ drop in economic growth. This result goes well with the fact that despite bank-based financial institutions dominate the MENA region's financial sector, the dominance of inefficient public banks led to poorer bank credit. This is in addition to the fact that many small firms in the MENA region are constrained in their ability to access financing via formal means reinforces the fact that limited access to finance lowers economic growth.

Table (21) adds the interaction terms of the governance indicator with the three measures of firms' access to finance finv, fwork, and $f c$, and their linear combination, firmacc, in order to analyze how improved institutions can affect the role of firms' access to finance on economic growth. Table (22) computes their total effects in the presence of good institutions, where the results show that the improvement in the institutional quality in the MENA region improves firms' access to finance and thereby increases economic growth, where firms' access measure is dominated by the positive statistically significant impact of the percentage of firms using bank loans to finance working capital. The results show that a one unit increase in the firmacc variable in the presence of improved institutions increases economic growth by $0.12 \%$.

\section{CONCLUSION}


The study analyzes the effect of access to finance to households and firms on economic growth for a sample of 23 EMs and 21 MENA countries over the period 1960-2015. Using Arellano-Bover/Blundell-Bond Dynamic Panel System GMM methodology, the studyfinds financial access, measured either by the IMF access indicators, households access measures, or firms access measures, are positive and statistically significantly in affecting economic growth across the full sample. The results of the MENA region indicate that households' measures of financial inclusion positively impact GDP per capita growth however this impact requires supervisory and regulatory regimes with backing of the rule of law, judicial independence, contract enforcement, control of corruption, and political stability. The results for the impact of the firms' access to finance are only statistically significant when complemented by strong institutions with the strongest impact stemming from the availability of firms' bank loans to finance working capital. The results reinforce the importance of private sector development, improved institutional quality, and increasing firm access to credit as a means to increase per capita growth.

\section{REFERENCES}

Abdmoulah, W. \& Jelili, R. B. (2013). Access to Finance Thresholds and the Finance-Growth Nexus. Economic Papers: A journal of applied economics and policy, 32 (4), 522-534.

Abuzayed, B. \& Fayoumi, N. (2016). Bank concentration, institutional quality, and economic growth: Empirical evidence from MENA countries, Review of International Business and Strategy, 26(2), $219-231$.

Ayadi, R., Arbak, E., Naceur, S.B., \& Groen, W. P. D. (2013). Financial Development, Bank Efficiency and Economic Growth across the Mediterranean. Online. Available at https://www.files.ethz.ch/isn/161854/Growth\%20\&\%20Development.pdf

Arellano, M. \& Bond, S. (1991). Some Tests of Specification for Panel Data: Monte Carlo Evidence and an Application to Employment Equations", Review of Economic Studies, 58, 277-297.

Arellano, M. \& Bover, O. (1995), Another Look at the Instrumental Variable Estimation of ErrorComponents Models, Journal of Econometrics, 68, 29-51.

Balach, R. \& Law, S.H. (2015). Effects of Financial Development, Institutional Quality, and Human Capital on Economic Performance in SAARC Countries. The empirical economics letters, 14 (February), 131-141.

Banerji, A. \& Humphreys, C. (2003) Better Governance for Development in the Middle East and North Africa: Enhancing Inclusiveness and Accountability, World Bank, ISBN: 978-0-82135635-7, https://doi.org/10.1596/0-8213-5635-6.

Blundell, R. \& Bond, S. (1998), Initial Conditions and Moment Restrictions in Dynamic Panel Data Models, Journal of Econometrics, 87, 115-143. 
Blundell, R.W., Bond, S.R. \& Windmeijer, F. (2000). Estimation in Dynamic Panel Data Models: Improving on the Performance of the Standard GMM Estimatorí, in B. Baltagi (ed.), Nonstationary Panels, Panel Cointegration, and Dynamic Panels, Advances in Econometrics 15, JAI Press, Elsevier Science.

Bacchetta, P. \& Gerlach, S. (1997). Consumption and Credit Constraints: International Evidence, Journal of Monetary Economics 40, 207-238.

Beck, T., Demirguc-Kunt, A., and Levine, R. (2007). Finance, Inequality, and the Poor. Journal of Economic Growth, 12 (1), pp. 7-49.

Beck, T. (2009). The Econometrics of Finance and Growth, in: Terence Mills and Kerry Patterson (Eds.): Palgrave Handbook of Econometrics, Vol. 2, Palgrave Macmillan.

Beck, T. (2016). Financial Inclusion - Measuring Progress and Progress in Measuring. Online. Available here.

Caselli, F., Esquivel, G., \& Lefort, F. (1996). Reopening the Convergence Debate: A New Look at Cross-Country Growth Empirics, Journal of Economic Growth, Springer, 1(3), 363-89, September.

Chauvet, L. \& Jacolin, L. (2017). Financial Inclusion, Bank Concentration, and Firm Performance. World Development, 97, issue C, 1-13

Cherif, M. \& Dreger, C. (2014). Institutional Determinants of Financial Development in MENA Countries. Online. Available at https://www.diw.de/documents/publikationen/73/diw 01.c.487179.de/dp1422.pdf

Cherif, M. \& Dreger, C. (2016), "Institutional Determinants of Financial Development in MENA Countries", Review of Development Economics, 20, 670-680.

Chinn, M.D., Ito, H. (2007). Current account balances, financial development and institutions: Assaying the world "saving glut, Journal of International Money and Finance, 26, 546-569.

Cihak, M., Mare, D.S., \& Melecky, M. (2016). The Nexus of Financial Inclusion and Financial Stability: A Study of Trade-Offs and Synergies. Online. Available here

Demetriades, P., \& Hook Law, S. (2006). Finance, institutions and economic development. International Journal of Finance and Economics, 11(3), 245.

Demirguc-Kunt, A., Klapper, L., Singer, D., and P.V. Oudheusden. (2015). The Global Findex Database 2014 Measuring Financial Inclusion around the World. World Bank Policy Research Working Paper 7255 .

Duncan, F. \& Denaux, Z. (2013). Determinants Of Economic Success In The Middle East And North Africa, Global Journal of Business Research, The Institute for Business and Finance Research, 7(5), 25-34.

Dupas, P., \& Robinson, J. (2013). Why Don't the Poor Save More? Evidence from Health Savings Experiments. American Economic Review, 103 (4), 1138-71.

Emara, N., \& Chiu, I. (2016). The Impact of Governance Environment on Economic Growth: The Case of Middle Eastern and North African Countries, 2016, Journal of Economics Library, 3(1), 24-37.

Emara, N., \& Jhonsa, E. (2014). Governance and Economic Growth: The Case of Middle East and North African Countries, 2014, Journal of Development and Economic Policies, 16(1), 4771. 
Emara, N., \& El Said, A. (2015). Revisiting Sovereign Ratings, Capital Flows, and Financial Contagion in Emerging Markets, 2015, World Journal of Applied Economics, 1(2), 3-22.

Gerschenkron, A. (1962). Economic backwardness in historical perspective, Harvard University Press, Cambridge, MA (1962)

Hall, R. \& Jones, C. (1999). Why Do Some Countries Produce So Much More Output Per Worker Thank Others? Quarterly Journal of Economics, 114(1), 83-116.

Hamdi, H. \& Hakimi, A. (2015). Did banks and financial markets developments lead to economic growth in MENA region? Evidence from Dynamic panel data estimation. Online. Available at https://mpra.ub.uni-muenchen.de/64310/

Holtz-Eakin, D., Newey, W., \& Rosen, H. (1988). Estimating Vector Autoregressions with Panel Data, Econometrica, 56, 1371-1395.

IMF. (2016). Capital Flows- Review of Experience with the Institutional View. Online. Available here

Kaufmann, D., Kraay, A., \& Zoido-Lobaton, P. (1999). Governance Matters. Manuscript, The World Bank.

Law, S. H., \& Habibullah, M. S. (2006). Financial Development, Institutional Quality and Economic Performance in East Asian Economies. Review of Applied Economics, 2(2).

Law, S. H. \& Kutan, A. M. \& Naseem, N.A.M., (2018). The role of institutions in finance curse: Evidence from international data, Journal of Comparative Economics, Elsevier, 46(1), 174191.

Magda, K. (2009). Determinants of institutional quality and their impact on economic growth in the MENA region, International Journal of Development Issues, 8(2), 134167, https://doi.org/10.1108/14468950910997693

Makdisi, S., Fattah, Z., \& Limam, I. (2003). Determinants of Growth in the MENA Region, Arab Planning Institute Working Paper No. 0301 (Kuwait). Available via the Internet: http://www.arab-api.org.

McKinnon, R. I. (1973). Money and Capital in Economic Development, Washington, DC: Brookings Institution.

Nabli, M.K. (2007). Breaking the Barriers to Higher Economic Growth: Better Reforms and Deeper Reforms in the Middle East and North Africa, Washington, DC: The World Bank.

Park, C. \& Mercado, R. (2015). Financial Inclusion, Poverty, and Income Inequality in Developing Asia, Asian Development Bank, Working Paper No. 426.

Rajan, R.G. \& Zingales, L. (2003). The great reversals: the politics of financial development in the twentieth century, Journal of Financial Economics, 69 (1) (July 2003), 5-50.

Rioja, F. \& Valev, N. (2004). Does one size fit all? A reexamination of the finance and growth relationship, Journal of Development Economics, 74, 429-447.

Rojas-Suarez, L., \& Gonzales. V. (2010). Access to Financial Services in Emerging Powers: Facts, Obstacles and Policy Implications, OECD Development Center, Background Paper. 
Sarma, M. \& Pais, J. (2011). Financial Inclusion and Development. Journal of International Development, 23, 613-625. https://doi.org/10.1002/jid.1698

Schumpeter, J. (1911). The theory of economic development: An inquiry into profits, capital, credit interest and business cycle, Harvard University Press, Cambridge, Massachusetts.

Svirydzenka, K. (2016). Introducing a New Broad-based Index of Financial Development. IMF Working Paper 16/5. Online. Available here

Jappelli, T., \& Pagano, M. (1989). Aggregate Consumption and Capital Market Imperfections: An International Comparison, American Economic Review, 79, 1088-1105.

Khan, M., \& Senhadji, A.S., (2003). Financial development and economic growth: a review and new evidence, Journal of African Economies, 12 (2), 89-110.

King, R.G., \& Levine, R. (1993a). Finance and Growth: Schumpeter Might Be Right, Quarterly Journal of Economics, 108, 717-738.

King, R. G. \& Levine, R. (1993b). Finance, Entrepreneurship, and Growth: Theory and Evidence, Journal of Monetary Economics, 32: 513-542.

King, R. G. \& Levine, R. (1993c). Financial Intermediation and Economic Development, In: Financial Intermediation in the Construction of Europe, Eds: C. Mayer and X. Vives, London: Centre for Economic Policy Research: 156-189.

Kitazawa (2003). Estimation of Persistence in Log-Volatility Using Panel Data, Applied Financial Economics, 13(6), 463-472.

Law, S.H., \& Habibullah, M. (2009) The determinants of financial development: institutions, openness and financial liberalization, South African Journal of Economics, 77 (1), 45-58.

Levine (2002), Bank-Based or Market-Based Financial Systems: Which Is Better? Journal of Financial Intermediation, 11, 398-428.

Levine, R. (2005). Finance and Growth: Theory and Evidence, Handbook of Economic Growth in: Philippe Aghion \& Steven Durlauf (ed.), Handbook of Economic Growth, edition 1, volume 1, chapter 12, pages 865-934 Elsevier.

Ludvigson, S. (1999). Consumption and Credit: A Model of Time-Varying Liquidity Constraints, The Review of Economics and Statistics, 81, 434-447.

Tissot, B. and B. Gadanecz. (2017). Measures of financial inclusion - a central bank perspective. Bank of Morocco - CEMLA - IFC Satellite Seminar at the ISI World Statistics Congress on "Financial Inclusion”, Marrakech, Morocco, 14 July 2017

Yafee, R. (2003). A Primer for Panel Data Analysis. Connect: Information Technology at NYU, (Fall), 1-11. 
Table 1 -List of EMs included in the Sample

\begin{tabular}{|l|l|l|l|}
\hline 1 & Argentina & 15 & Philippines \\
\hline 2 & Bangladesh & 16 & Poland \\
\hline 3 & Brazil & 17 & Romania \\
\hline 4 & Bulgaria & 18 & Russia \\
\hline 5 & Chile & 19 & South Africa \\
\hline 6 & China & 20 & Thailand \\
\hline 7 & Columbia & 21 & Turkey \\
\hline 8 & Hungary & 22 & Ukraine \\
\hline 9 & India & 23 & Venezuela \\
\hline 10 & Indonesia & & \\
\hline 11 & Malaysia & & \\
\hline 12 & Mexico & & \\
\hline 13 & Pakistan & & \\
\hline 14 & Peru & & \\
\hline
\end{tabular}

Table 2 -List of MENA included in the Sample

\begin{tabular}{|l|l|l|l|}
\hline 1 & Algeria & 15 & Qatar \\
\hline 2 & Bahrain & 16 & Saudi Arabia \\
\hline 3 & Djibouti & 17 & Syria \\
\hline 4 & Egypt & 18 & Tunisia \\
\hline 5 & Iran & 19 & United Arab Emirates \\
\hline 6 & Iraq & 20 & West Bank \& Gaza \\
\hline 7 & Israel & 21 & Yemen \\
\hline 8 & Jordan & & \\
\hline 9 & Kuwait & & \\
\hline 10 & Lebanon & & \\
\hline 11 & Libya & & \\
\hline 12 & Malta & & \\
\hline 13 & Morocco & & \\
\hline 14 & Oman & & \\
\hline
\end{tabular}


Table 3 - Definitions of Economic Variables

\begin{tabular}{|c|c|c|c|c|}
\hline Variable Name & WDI Definition & $\begin{array}{c}\text { Unit of } \\
\text { Measurement }\end{array}$ & Data Source & Abbreviation \\
\hline Growth & $\begin{array}{l}\text { Computed as the change in the log GDP per capita (constant } \\
2010 \text { US\$) (Author computation). GDP per capita is gross } \\
\text { domestic product divided by midyear population. GDP is the } \\
\text { sum of gross value added by all resident producers in the } \\
\text { economy plus any product taxes and minus any subsidies not } \\
\text { included in the value of the products. It is calculated without } \\
\text { making deductions for depreciation of fabricated assets or for } \\
\text { depletion and degradation of natural resources. Data are in } \\
\text { constant } 2010 \text { U.S. dollars. }\end{array}$ & Percent & $\begin{array}{l}\text { World Development } \\
\text { Indicators. }\end{array}$ & $g r$ \\
\hline Inflation & $\begin{array}{l}\text { Change in the log of Consumer price index }(2010=100) \\
\text { (Authors computation). }\end{array}$ & Percent & $\begin{array}{l}\text { World Development } \\
\text { Indicators. }\end{array}$ & $\inf$ \\
\hline Investment & $\begin{array}{l}\text { Change in the log of Gross capital formation (constant } 2010 \\
\text { US\$). }\end{array}$ & Percent & $\begin{array}{l}\text { World Development } \\
\text { Indicators. }\end{array}$ & govexp \\
\hline $\begin{array}{l}\text { Government } \\
\text { expenditure }(\% \text { of } \\
\text { GDP) }\end{array}$ & $\begin{array}{l}\text { General government final consumption expenditure (formerly } \\
\text { general government consumption) includes all government } \\
\text { current expenditures for purchases of goods and services } \\
\text { (including compensation of employees). It also includes most } \\
\text { expenditures on national defense and security, but excludes } \\
\text { government military expenditures that are part of government } \\
\text { capital formation. }\end{array}$ & Percent & $\begin{array}{l}\text { World Development } \\
\text { Indicators. }\end{array}$ & govexp \\
\hline Openness & $\begin{array}{l}\text { Exports of goods and services (constant } 2010 \text { US\$) Imports of } \\
\text { goods and services (constant } 2010 \text { US\$) } \\
\text { GDP (constant } 2010 \text { US\$) }\end{array}$ & Percent & $\begin{array}{l}\text { World Development } \\
\text { Indicators. }\end{array}$ & $o p$ \\
\hline $\begin{array}{l}\text { Population } \\
\text { Growth }\end{array}$ & Change in the log of Population (Total). & Percent & $\begin{array}{l}\text { World Development } \\
\text { Indicators. }\end{array}$ & popgr \\
\hline
\end{tabular}

Table 4 - Definitions of Households' Financial Inclusion Variables

\begin{tabular}{|c|c|c|c|}
\hline Indicator & Definition & Periodicity & Abbreviation \\
\hline Bank accounts per 1,000 adults & Number of depositors with commercial banks per 1,000 adults. & $2001-2015$ & $b a$ \\
\hline ATMs per 100,000 adults & Number of ATMs per 100,000 adults. & $2001-2015$ & atm \\
\hline Bank branches per 100,000 adults & Bank branches per 100,000 adults & $2001-2015$ & $b b$ \\
\hline acc & $\begin{array}{l}\text { The principal component of the last three indicators (Author } \\
\text { computation) }\end{array}$ & $2001-2015$ & $a c c$ \\
\hline
\end{tabular}

Source: World Development Indicators

Table 5 - Definitions of Firms' Financial Inclusion Variables

\begin{tabular}{|c|c|c|c|}
\hline Indicator & Definition & Periodicity & Abbreviation \\
\hline $\begin{array}{l}\text { Firms using banks to finance } \\
\text { investments ( } \% \text { of firms) }\end{array}$ & $\begin{array}{l}\text { The percentage of firms using } \\
\text { banks to finance investments. }\end{array}$ & $2007-2015$ & fiv \\
\hline $\begin{array}{l}\text { Firms using banks to finance } \\
\text { working capital ( } \% \text { of firms) }\end{array}$ & $\begin{array}{l}\text { The percentage of firms using } \\
\text { bank loans to finance working } \\
\text { capital. }\end{array}$ & $2007-2015$ & fwork \\
\hline $\begin{array}{l}\text { Firms identifying access to } \\
\text { finance as a major constraint ( } \% \\
\text { of firms) }\end{array}$ & $\begin{array}{l}\text { Firms identifying access to } \\
\text { finance as a major constraint } \\
\text { (\% of firms) }\end{array}$ & $2007-2015$ & $f_{c}$ \\
\hline firmacc & $\begin{array}{l}\text { The principal component of } \\
\text { the last three indicators } \\
\text { (Author computation) }\end{array}$ & $2007-2015$ & firmacc \\
\hline
\end{tabular}

Source: World Development Indicators. 
Table 6 - Definitions of General Access Variables

\begin{tabular}{|c|c|c|c|}
\hline Indicator & Definition & Periodicity & Abbreviation \\
\hline Financial Institutions Access Index & $\begin{array}{l}\text { Number of ATMs per } 100,000 \text { adults. } \\
\text { Bank branches per } 100,000 \text { adults }\end{array}$ & $1980-2014$ & fia \\
\hline Financial Markets Access Index & $\begin{array}{l}\text { The percent of market capitalization outside of top } 10 \text { largest } \\
\text { companies } \\
\text { Total number of issuers of debt (domestic and external, nonfinancial } \\
\text { and financial corporations) }\end{array}$ & $1980-2014$ & fma \\
\hline Financial Access General Index & Principal component analysis of fia and fma & $1980-2014$ & accgen \\
\hline
\end{tabular}

Source: Katsiaryna Svirydzenka Introducing a New Broad-based Index of Financial Development, IMF Working Paper No. 16/5, January 12, 2016

Table 7 - Definitions of Governance Indicators

\begin{tabular}{|l|l|l|}
\hline Indicator & Periodicity & Abbreviation \\
\hline Control of Corruption & $1996-2015$ & corrup \\
\hline Government Effectiveness & $1996-2015$ & goveff \\
\hline $\begin{array}{l}\text { Political Stability and Absence of } \\
\text { Violence/Terrorism }\end{array}$ & $1996-2015$ & pols \\
\hline Regulatory Quality & $1996-2015$ & regq \\
\hline Rule of Law & $1996-2015$ & rl \\
\hline Voice and Accountability & $1996-2015$ & vacc \\
\hline Governance & $1996-2015$ & gov \\
\hline
\end{tabular}

Source: World Development Indicators 
Table 8: General Access to Finance \& Economic Growth

Dependent variable: Economic Growth

Estimation Method: Dynamic Panel System GMM

\begin{tabular}{|c|c|c|c|c|c|c|}
\hline Regressors & (1) & (2) & (3) & (4) & $(5)$ & (6) \\
\hline$L . g r$ & $\begin{array}{c}0.240 * * * \\
(0.0457)\end{array}$ & $\begin{array}{c}0.263 * * * \\
(0.0548)\end{array}$ & $\begin{array}{c}0.250 * * * \\
(0.0488)\end{array}$ & $\begin{array}{c}0.249 * * * \\
(0.0485)\end{array}$ & $\begin{array}{c}0.245^{* * *} \\
(0.0475)\end{array}$ & $\begin{array}{c}0.244 * * * \\
(0.0473)\end{array}$ \\
\hline inf & $\begin{array}{l}-0.0228^{*} \\
(0.0130)\end{array}$ & $\begin{array}{l}-0.0222 \\
(0.0138)\end{array}$ & $\begin{array}{l}-0.0198 \\
(0.0122)\end{array}$ & $\begin{array}{l}-0.0198 \\
(0.0122)\end{array}$ & $\begin{array}{l}-0.0212 * \\
(0.0127)\end{array}$ & $\begin{array}{l}-0.0213^{*} \\
(0.0128)\end{array}$ \\
\hline$i n v$ & $\begin{array}{c}0.0770^{* *} \\
(0.0349)\end{array}$ & $\begin{array}{c}0.0766^{* *} \\
(0.0355)\end{array}$ & $\begin{array}{l}0.0778 * * \\
(0.0350)\end{array}$ & $\begin{array}{c}0.0778 * * \\
(0.0349)\end{array}$ & $\begin{array}{l}0.0774 * * \\
(0.0349)\end{array}$ & $\begin{array}{c}0.0774 * * \\
(0.0349)\end{array}$ \\
\hline govexp & $\begin{array}{l}-0.0726 \\
(0.0612)\end{array}$ & $\begin{array}{l}-0.0024 \\
(0.0379)\end{array}$ & $\begin{array}{l}-0.0357 \\
(0.0513)\end{array}$ & $\begin{array}{l}-0.000352 \\
(0.000513)\end{array}$ & $\begin{array}{l}-0.0619 \\
(0.0572)\end{array}$ & $\begin{array}{l}-0.0607 \\
(0.0579)\end{array}$ \\
\hline$o p$ & $\begin{array}{l}0.0059 * * \\
(0.0029)\end{array}$ & $\begin{array}{l}0.0054 * * \\
(0.0025)\end{array}$ & $\begin{array}{l}0.0057 * * \\
(0.0025)\end{array}$ & $\begin{array}{c}0.0056^{* *} \\
(0.0026)\end{array}$ & $\begin{array}{l}0.0058 * * \\
(0.0027)\end{array}$ & $\begin{array}{c}0.0058 * * \\
(0.0028)\end{array}$ \\
\hline popgr & $\begin{array}{c}0.593 * * \\
(0.241)\end{array}$ & & $\begin{array}{c}0.524 * * \\
(0.213)\end{array}$ & $\begin{array}{c}0.523 * * \\
(0.213)\end{array}$ & $\begin{array}{c}0.566^{* *} \\
(0.228)\end{array}$ & $\begin{array}{c}0.565 * * \\
(0.229)\end{array}$ \\
\hline $\begin{array}{l}\text { fia } \\
\text { fiaMENA }\end{array}$ & $\begin{array}{c}0.0324 * * \\
(0.0126)\end{array}$ & $\begin{array}{c}0.0266 * * * \\
(0.0102) \\
-0.00284 \\
(0.0182)\end{array}$ & & & & \\
\hline $\begin{array}{l}\text { fma } \\
\text { fmaMENA }\end{array}$ & & & $\begin{array}{l}0.0111 * * \\
(0.00517)\end{array}$ & $\begin{array}{c}0.0123 * \\
(0.00647) \\
-0.00520 \\
(0.0131)\end{array}$ & & \\
\hline $\begin{array}{l}\text { accgen } \\
\text { accgenMENA }\end{array}$ & & & & & $\begin{array}{c}0.0287 * * \\
(0.0116)\end{array}$ & $\begin{array}{c}0.0299 * * \\
(0.0128) \\
-0.00695 \\
(0.0167)\end{array}$ \\
\hline Observations & 746 & 746 & 746 & 746 & 746 & 746 \\
\hline Countries & 34 & 34 & 34 & 34 & 34 & 34 \\
\hline $\begin{array}{l}\text { Chi-Sq. Stat. } \\
\text { Sargan Pvalue }\end{array}$ & $\begin{array}{c}375.3 \\
{[0.091]}\end{array}$ & $\begin{array}{l}334.97 \\
{[0.065]}\end{array}$ & $\begin{array}{l}395.90 \\
{[0.029]}\end{array}$ & $\begin{array}{l}334.91 \\
{[0.032]}\end{array}$ & $\begin{array}{l}335.92 \\
{[0.031]}\end{array}$ & $\begin{array}{l}362.97 \\
{[0.066]}\end{array}$ \\
\hline
\end{tabular}

Note: Robust standard errors in parentheses, ${ }^{* * *} \mathrm{p}<0.01,{ }^{* *} \mathrm{p}<0.05,{ }^{*} \mathrm{p}<0.1$ 
Table 9: MENA Total Effects of

$$
\text { Access to Finance }
$$

\begin{tabular}{|c|c|}
\hline Regressors & Total Effect \\
\hline fia & 0.024 \\
& $(0.019)$ \\
\hline fma & 0.007 \\
& $(0.011)$ \\
\hline accgen & 0.023 \\
& $(0.015)$ \\
\hline
\end{tabular}


Table 10: General Access To Finance \& Economic Growth With Governance Dependent variable: Economic Growth

Estimation Method: Dynamic Panel System GMM

\begin{tabular}{|c|c|c|c|}
\hline Regressors & $(1)$ & $(2)$ & (3) \\
\hline$L . g r$ & $\begin{array}{l}0.148^{* *} \\
(0.0629)\end{array}$ & $\begin{array}{c}0.159 * * * \\
(0.0577)\end{array}$ & $\begin{array}{l}0.151 * * \\
(0.0608)\end{array}$ \\
\hline $\inf$ & $\begin{array}{c}-0.110 * * * \\
(0.0365)\end{array}$ & $\begin{array}{c}-0.108 * * * \\
(0.0386)\end{array}$ & $\begin{array}{c}-0.110 * * * \\
(0.0374)\end{array}$ \\
\hline$i n v$ & $\begin{array}{c}0.0827 * * \\
(0.0381)\end{array}$ & $\begin{array}{l}0.0838 * * \\
(0.0392)\end{array}$ & $\begin{array}{l}0.0831 * * \\
(0.0384)\end{array}$ \\
\hline govexp & $\begin{array}{l}-0.0625 \\
(0.0669)\end{array}$ & $\begin{array}{l}-0.0436 \\
(0.0565)\end{array}$ & $\begin{array}{l}-0.0638 \\
(0.0652)\end{array}$ \\
\hline$o p$ & $\begin{array}{c}0.0193 \\
(0.0142)\end{array}$ & $\begin{array}{c}0.0193 \\
(0.0149)\end{array}$ & $\begin{array}{c}0.0192 \\
(0.0148)\end{array}$ \\
\hline popgr & $\begin{array}{c}0.262 \\
(0.226)\end{array}$ & $\begin{array}{c}0.199 \\
(0.270)\end{array}$ & $\begin{array}{c}0.236 \\
(0.244)\end{array}$ \\
\hline fia & $\begin{array}{c}0.0414 * * * \\
(0.0120)\end{array}$ & & \\
\hline fiagovMENA & $\begin{array}{l}-0.0100 \\
(0.106)\end{array}$ & & \\
\hline$f m a$ & & $\begin{array}{c}0.0522 * * * \\
(0.0188)\end{array}$ & \\
\hline fmagovMENA & & $\begin{array}{c}-0.000396 \\
(0.101)\end{array}$ & \\
\hline accgen & & & $\begin{array}{c}0.0567 * * * \\
(0.0154)\end{array}$ \\
\hline accgengovMENA & & & $\begin{array}{c}0.00418 \\
(0.115)\end{array}$ \\
\hline Observations & 331 & 331 & 331 \\
\hline Countries & 32 & 32 & 32 \\
\hline $\begin{array}{l}\text { Chi-Sq. Stat. Sargan } \\
\text { Pvalue }\end{array}$ & $\begin{array}{l}395.90 \\
{[0.029]} \\
\end{array}$ & $\begin{array}{l}335.92 \\
{[0.031]}\end{array}$ & $\begin{array}{l}362.97 \\
{[0.066]}\end{array}$ \\
\hline
\end{tabular}


Note: Robust standard errors in parentheses, ${ }^{* * *} \mathrm{p}<0.01, * * \mathrm{p}<0.05, * \mathrm{p}<0.1$

Table 11: MENA Total Effects of General

Access to Finance With Governance

\begin{tabular}{|c|c|}
\hline Regressors & Total Effect \\
\hline fia ${ }^{*}$ gov & 0.031 \\
& $(0.110)$ \\
\hline fma ${ }^{*}$ gov & 0.052 \\
& $(0.102)$ \\
\hline accgen $^{*}$ gov & 0.061 \\
& $(0.117)$ \\
\hline
\end{tabular}


Table 12: HH's Access to Finance \& Economic Growth

Dependent variable: Economic Growth

\begin{tabular}{|c|c|c|c|c|c|c|}
\hline Regressors & $(1)$ & $(2)$ & (3) & (4) & $(5)$ & $(6)$ \\
\hline$L . g r$ & $\begin{array}{c}0.0487 \\
(0.0634)\end{array}$ & $\begin{array}{c}0.0450 \\
(0.0636)\end{array}$ & $\begin{array}{c}0.0470 \\
(0.0615)\end{array}$ & $\begin{array}{c}0.0462 \\
(0.0622)\end{array}$ & $\begin{array}{l}0.0827 \\
(0.120)\end{array}$ & $\begin{array}{l}0.0775 \\
(0.120)\end{array}$ \\
\hline $\inf$ & $\begin{array}{c}-0.0498 * * * \\
(0.00629)\end{array}$ & $\begin{array}{c}-0.0455 * * * \\
(0.00670)\end{array}$ & $\begin{array}{c}-0.0436 * * * \\
(0.00612)\end{array}$ & $\begin{array}{c}-0.0432 * * * \\
(0.00625)\end{array}$ & $\begin{array}{c}-0.0466 * * * \\
(0.00371)\end{array}$ & $\begin{array}{c}-0.0488 * * * \\
(0.00402)\end{array}$ \\
\hline inv & $\begin{array}{c}0.168 * * * \\
(0.0166)\end{array}$ & $\begin{array}{c}0.169 * * * \\
(0.0168)\end{array}$ & $\begin{array}{c}0.168 * * * \\
(0.0164)\end{array}$ & $\begin{array}{c}0.168 * * * \\
(0.0164)\end{array}$ & $\begin{array}{c}0.191 * * * \\
(0.0167)\end{array}$ & $\begin{array}{c}0.189 * * * \\
(0.0166)\end{array}$ \\
\hline govexp & $\begin{array}{c}-0.0714^{* *} \\
(0.0361)\end{array}$ & $\begin{array}{l}-0.0333 \\
(0.0380)\end{array}$ & $\begin{array}{l}-0.0228 \\
(0.0440)\end{array}$ & $\begin{array}{l}-0.0234 \\
(0.0443)\end{array}$ & $\begin{array}{l}-0.0610 \\
(0.0513)\end{array}$ & $\begin{array}{l}-0.0351 \\
(0.0467)\end{array}$ \\
\hline$o p$ & $\begin{array}{c}0.0258^{* * * *} \\
(0.0001)\end{array}$ & $\begin{array}{c}0.0266^{* * * *} \\
(0.0001)\end{array}$ & $\begin{array}{c}0.0238^{* *} \\
(0.0111)\end{array}$ & $\begin{array}{c}0.0230^{* *} \\
(0.0111)\end{array}$ & $\begin{array}{c}0.005 \\
(0.008)\end{array}$ & $\begin{array}{c}0.004 \\
(0.007)\end{array}$ \\
\hline popgr & $\begin{array}{c}0.496^{* *} \\
(0.207)\end{array}$ & & $\begin{array}{l}0.416^{*} \\
(0.228)\end{array}$ & $\begin{array}{c}0.375 \\
(0.241)\end{array}$ & $\begin{array}{c}0.332 \\
(0.429)\end{array}$ & $\begin{array}{c}0.343 \\
(0.403)\end{array}$ \\
\hline $\begin{array}{l}\text { atm } \\
\text { atmMENA }\end{array}$ & $\begin{array}{c}0.0208 * * * \\
(0.007)\end{array}$ & $\begin{array}{c}0.0180 * * * \\
(0.007) \\
-0.003 \\
(0.0008)\end{array}$ & & & & \\
\hline$b b$ & & & $\begin{array}{c}0.0161 * \\
(0.001)\end{array}$ & $\begin{array}{l}0.0158^{*} \\
(0.0001)\end{array}$ & & \\
\hline bbMENA & & & & $\begin{array}{c}0.0207 \\
(0.0197)\end{array}$ & & \\
\hline$b a$ & & & & & $\begin{array}{c}0.003 * * * \\
(0.001)\end{array}$ & $\begin{array}{c}0.003 * * * \\
(0.001)\end{array}$ \\
\hline baMENA & & & & & & $\begin{array}{l}-0.001 * * \\
(0.0007)\end{array}$ \\
\hline Observations & 223 & 223 & 226 & 226 & 115 & 115 \\
\hline Countries & 19 & 19 & 19 & 19 & 13 & 13 \\
\hline $\begin{array}{l}\text { Chi-Sq. Stat. } \\
\text { Sargan Pvalue }\end{array}$ & $\begin{array}{l}358.3 \\
{[0.09]}\end{array}$ & $\begin{array}{l}362.97 \\
{[0.066]}\end{array}$ & $\begin{array}{l}377.30 \\
{[0.028]}\end{array}$ & $\begin{array}{l}374.92 \\
{[0.031]}\end{array}$ & $\begin{array}{l}232.99 \\
{[0.026]}\end{array}$ & $\begin{array}{l}227.38 \\
{[0.041]}\end{array}$ \\
\hline
\end{tabular}

Note: Robust standard errors in parentheses, *** $\mathrm{p}<0.01, * * \mathrm{p}<0.05, * \mathrm{p}<0.1$ 
Table 13: HH's Access to Finance \& Economic Growth

Dependent variable: Economic Growth

Estimation Method: Dynamic Panel System GMM

\begin{tabular}{lcc}
\hline Regressors & $(1)$ & $(2)$ \\
\hline \multirow{2}{*}{ L.gr } & 0.0805 & 0.0737 \\
& $(0.125)$ & $(0.126)$ \\
inf & $-0.0471^{* * *}$ & $-0.0493^{* * *}$ \\
& $(0.00401)$ & $(0.00439)$ \\
inv & $0.191 * * *$ & $0.190^{* * *}$ \\
& $(0.0170)$ & $(0.0168)$ \\
govexp & -0.0717 & -0.0450 \\
& $(0.0547)$ & $(0.0519)$ \\
op & 0.007 & 0.006 \\
& $(0.008)$ & $(0.008)$ \\
popgr & 0.390 & 0.404 \\
& $(0.470)$ & $(0.450)$ \\
acc & $0.007 * * *$ & $0.007 * * *$ \\
& $(0.002)$ & $(0.002)$ \\
accMENA & & $-0.003 * *$ \\
& & $(0.0016)$ \\
& & \\
\hline Observations & 113 & 113 \\
Countries & 13 & 13 \\
\hline Chi-Sq. Stat. & 229.93 & 224.57 \\
Sargan P-value & {$[0.022]$} & $0.0351]$ \\
\hline \multicolumn{2}{c}{ Robust standard errors in parentheses }
\end{tabular}

Robust standard errors in parentheses

$* * * \mathrm{p}<0.01, * * \mathrm{p}<0.05, * \mathrm{p}<0.1$ 
Table 14: MENA Total Effects

of HH's Access to Finance

\begin{tabular}{|l|l|}
\hline Regressors & Total Effect \\
\hline
\end{tabular}

atm $0.015^{*}$

$(0.009)$

\begin{tabular}{|c|c|}
\hline$b b$ & $\begin{array}{c}0.037^{*} \\
(0.02)\end{array}$ \\
\hline$b a$ & $0.0017^{* *}$ \\
& $(0.001)$ \\
\hline$a c c$ & $0.0036^{* *}$ \\
& $(0.002)$ \\
\hline
\end{tabular}


Table 15: HH's Access To Finance \& Economic Growth With Governance

Dependent variable: Economic Growth

\begin{tabular}{|c|c|c|c|c|}
\hline Regressors & $(1)$ & $(2)$ & (3) & (4) \\
\hline L.gr & $\begin{array}{l}-0.0458 \\
(0.0808)\end{array}$ & $\begin{array}{l}-0.0579 \\
(0.0743)\end{array}$ & $\begin{array}{l}0.0895 \\
(0.168)\end{array}$ & $\begin{array}{l}0.0764 \\
(0.167)\end{array}$ \\
\hline $\inf$ & $\begin{array}{l}-0.0837 \\
(0.0603)\end{array}$ & $\begin{array}{l}-0.0738 \\
(0.0658)\end{array}$ & $\begin{array}{c}0.0399 \\
(0.0622)\end{array}$ & $\begin{array}{c}0.0264 \\
(0.0613)\end{array}$ \\
\hline inv & $\begin{array}{c}0.183 * * * \\
(0.0265)\end{array}$ & $\begin{array}{c}0.174 * * * \\
(0.0221)\end{array}$ & $\begin{array}{l}0.155^{* *} \\
(0.0660)\end{array}$ & $\begin{array}{l}0.144 * * \\
(0.0625)\end{array}$ \\
\hline govexp & $\begin{array}{c}-0.112 \\
(0.0708)\end{array}$ & $\begin{array}{l}-0.0017 \\
(0.0741)\end{array}$ & $\begin{array}{c}-0.0978 * * \\
(0.0482)\end{array}$ & $\begin{array}{c}-0.136 * * * \\
(0.0454)\end{array}$ \\
\hline$o p$ & $\begin{array}{c}0.0352^{* * * *} \\
(0.0105)\end{array}$ & $\begin{array}{l}0.0265^{*} \\
(0.0144)\end{array}$ & $\begin{array}{c}0.0105 \\
(0.0136)\end{array}$ & $\begin{array}{c}0.0159 \\
(0.0122)\end{array}$ \\
\hline popgr & $\begin{array}{c}0.470 \\
(0.404)\end{array}$ & $\begin{array}{c}0.329 \\
(0.503)\end{array}$ & $\begin{array}{r}-0.0997 \\
(0.165)\end{array}$ & $\begin{array}{c}-0.238 \\
(0.165)\end{array}$ \\
\hline atm & $\begin{array}{c}0.0309 * * * \\
(0.0075)\end{array}$ & & & \\
\hline atmgovMENA & $\begin{array}{c}0.0058 \\
(0.0189)\end{array}$ & & & \\
\hline$b b$ & & $\begin{array}{l}0.0154^{*} \\
(0.0079)\end{array}$ & & \\
\hline bbgovMENA & & $\begin{array}{c}0.0476 \\
(0.0530)\end{array}$ & & \\
\hline$b a$ & & & $\begin{array}{l}0.0041 * \\
(0.0021)\end{array}$ & \\
\hline bagovMENA & & & $\begin{array}{l}-0.0012 \\
(0.0012)\end{array}$ & \\
\hline$a c c$ & & & & $\begin{array}{c}0.0101 * * \\
(0.0043)\end{array}$ \\
\hline accgovMENA & & & & $\begin{array}{l}-0.0031 \\
(0.0025)\end{array}$ \\
\hline
\end{tabular}

Observations 


\begin{tabular}{lcccc} 
Countries & 11 & 11 & 8 & 8 \\
\hline Chi-Sq. Stat. & 160.42 & 178.19 & 88.24 & 86.47 \\
Sargan P-value & {$[0.07]$} & {$[0.01]$} & {$[0.33]$} & {$[0.32]$} \\
\hline \multicolumn{4}{c}{ Note: Robust standard errors in parentheses, ${ }^{* * *} \mathrm{p}<0.01, * * \mathrm{p}<0.05, * \mathrm{p}<0.1$}
\end{tabular}

Note: Robust standard errors in parentheses, ${ }^{* * *} \mathrm{p}<0.01,{ }^{* *} \mathrm{p}<0.05,{ }^{*} \mathrm{p}<0.1$

Table 16: MENA Total Effects of HH's Access

\begin{tabular}{|c|c|} 
to Finance with Governance \\
\hline Regressors & Total Effect \\
\hline$a t m * g o v$ & $0.037 * *$ \\
& $(0.018)$ \\
\hline$b b^{*}$ gov & 0.063 \\
& $(0.056)$ \\
\hline$b a^{*}$ gov & $0.003 * *$ \\
& $(0.001)$ \\
\hline$a c *^{*}$ gov & $0.0070^{* * *}$ \\
& $(0.002)$ \\
\hline
\end{tabular}

Table 17: MENA Total Effects of HH's Access to Finance

With Components of Governance in MENA Countries

\begin{tabular}{|c|c|}
\hline Regressors & Total Effect \\
\hline$a c c *$ corr & $0.0076^{* * *}$ \\
& $(0.002)$ \\
\hline$a c{ }^{*}$ geff & $0.0074^{* * *}$ \\
& $(0.0021)$ \\
\hline$a c *^{*}$ pols & $0.013^{* *}$ \\
& $(0.005)$ \\
\hline$a c c * r e g q$ & $0.0079^{* *}$ \\
& $(0.003)$ \\
\hline$a c{ }^{*} r l$ & $0.0076^{* * *}$ \\
& $(0.002)$ \\
\hline$a c{ }^{*} v a c$ & $0.007 * * *$ \\
& $(0.002)$ \\
\hline
\end{tabular}


Table 18: Firm's Access to Finance \& Economic Growth

Dependent variable: Economic Growth

Estimation Method: Dynamic Panel System GMM

\begin{tabular}{|c|c|c|c|c|c|c|}
\hline Regressors & $(1)$ & (2) & (3) & (4) & $(5)$ & $(6)$ \\
\hline L.gr & $\begin{array}{c}0.135 \\
(0.130)\end{array}$ & $\begin{array}{c}0.147 \\
(0.124)\end{array}$ & $\begin{array}{c}0.112 \\
(0.145)\end{array}$ & $\begin{array}{c}0.130 \\
(0.136)\end{array}$ & $\begin{array}{c}0.178 \\
(0.128)\end{array}$ & $\begin{array}{c}0.162 \\
(0.121)\end{array}$ \\
\hline inf & $\begin{array}{c}-0.0846^{* * * *} \\
(0.0219)\end{array}$ & $\begin{array}{c}-0.0916^{* * *} \\
(0.0216)\end{array}$ & $\begin{array}{c}-0.0898 * * * \\
(0.0220)\end{array}$ & $\begin{array}{c}-0.0970 * * * \\
(0.0220)\end{array}$ & $\begin{array}{c}-0.0806^{* * * *} \\
(0.0169)\end{array}$ & $\begin{array}{c}-0.0890 * * * \\
(0.0143)\end{array}$ \\
\hline inv & $\begin{array}{c}0.0656 * * * \\
(0.0175)\end{array}$ & $\begin{array}{c}0.0714 * * * \\
(0.0175)\end{array}$ & $\begin{array}{c}0.0713 * * * \\
(0.0168)\end{array}$ & $\begin{array}{c}0.0766^{* * * *} \\
(0.0170)\end{array}$ & $\begin{array}{c}0.0679 * * * \\
(0.0159)\end{array}$ & $\begin{array}{c}0.0716^{* * *} \\
(0.0149)\end{array}$ \\
\hline govexp & $\begin{array}{l}-0.0184 \\
(0.0580)\end{array}$ & $\begin{array}{c}0.0437 \\
(0.0450)\end{array}$ & $\begin{array}{l}-0.0348 \\
(0.0579)\end{array}$ & $\begin{array}{c}0.0156 \\
(0.0504)\end{array}$ & $\begin{array}{c}0.117 \\
(0.101)\end{array}$ & $\begin{array}{l}0.0999 \\
(0.101)\end{array}$ \\
\hline$o p$ & $\begin{array}{c}0.005 \\
(0.009)\end{array}$ & $\begin{array}{l}-0.002 \\
(0.009)\end{array}$ & $\begin{array}{c}0.001 \\
(0.0103)\end{array}$ & $\begin{array}{c}-0.002 \\
(0.0111)\end{array}$ & $\begin{array}{c}0.007 \\
(0.0106)\end{array}$ & $\begin{array}{c}0.009 \\
(0.0102)\end{array}$ \\
\hline popgr & $\begin{array}{c}0.663 * * \\
(0.336)\end{array}$ & $\begin{array}{c}0.919 * * * \\
(0.299)\end{array}$ & $\begin{array}{c}0.800 * * \\
(0.348)\end{array}$ & $\begin{array}{c}1.067 * * * \\
(0.290)\end{array}$ & $\begin{array}{c}0.998 * * \\
(0.411)\end{array}$ & $\begin{array}{c}1.233 * * * \\
(0.411)\end{array}$ \\
\hline finv & $\begin{array}{c}0.0732 * * * \\
(0.0231)\end{array}$ & $\begin{array}{c}0.0660 * * * \\
(0.0219)\end{array}$ & & & & \\
\hline finvMENA & & $\begin{array}{c}-0.0935 * * * \\
(0.0202)\end{array}$ & & & & \\
\hline fwork & & & $\begin{array}{c}0.0692 * * * \\
(0.0223)\end{array}$ & $\begin{array}{c}0.0634 * * * \\
(0.0203)\end{array}$ & & \\
\hline fworkMENA & & & & $\begin{array}{c}-0.0865 * * * \\
(0.0170)\end{array}$ & & \\
\hline$f_{c}$ & & & & & $\begin{array}{l}-0.0241 \\
(0.0567)\end{array}$ & $\begin{array}{c}0.003 \\
(0.0644)\end{array}$ \\
\hline$f c M E N A$ & & & & & & $\begin{array}{c}-0.0778 * * \\
(0.0335)\end{array}$ \\
\hline Observations & 54 & 54 & 52 & 52 & 54 & 54 \\
\hline Countries & 18 & 18 & 18 & 18 & 18 & 18 \\
\hline $\begin{array}{l}\text { Chi-Sq. Stat. } \\
\text { Sargan P-value }\end{array}$ & $\begin{array}{r}27.69 \\
{[0.998]} \\
\end{array}$ & $\begin{array}{c}19.63 \\
{[0.999]}\end{array}$ & $\begin{array}{c}27.52 \\
{[0.998]}\end{array}$ & $\begin{array}{l}18.99 \\
{[0.999]}\end{array}$ & $\begin{array}{l}18.65 \\
{[0.999]}\end{array}$ & $\begin{array}{c}19.79 \\
{[0.999]}\end{array}$ \\
\hline
\end{tabular}

Note: Robust standard errors in parentheses, ${ }^{* * *} \mathrm{p}<0.01,{ }^{* *} \mathrm{p}<0.05,{ }^{*} \mathrm{p}<0.1$ 
Table 19: Firm's Access To Finance \& Economic Growth

\begin{tabular}{|c|c|c|}
\hline Regressors & (1) & $(2)$ \\
\hline$L . g r$ & $\begin{array}{c}0.112 \\
(0.139)\end{array}$ & $\begin{array}{c}0.129 \\
(0.132)\end{array}$ \\
\hline $\inf$ & $\begin{array}{c}-0.0874 * * * \\
(0.0220)\end{array}$ & $\begin{array}{c}-0.0943 * * * \\
(0.0215)\end{array}$ \\
\hline inv & $\begin{array}{c}0.0685^{* * *} \\
(0.0170)\end{array}$ & $\begin{array}{c}0.0739 * * * \\
(0.0170)\end{array}$ \\
\hline govexp & $\begin{array}{l}-0.0479 \\
(0.0621)\end{array}$ & $\begin{array}{c}0.0136 \\
(0.0565)\end{array}$ \\
\hline$o p$ & $\begin{array}{l}0.003 \\
(0.01)\end{array}$ & $\begin{array}{r}-0.002 \\
(0.01)\end{array}$ \\
\hline popgr & $\begin{array}{c}0.745^{* *} \\
(0.355)\end{array}$ & $\begin{array}{c}1.016^{* * *} \\
(0.302)\end{array}$ \\
\hline firmacc & $\begin{array}{c}0.0804 * * * \\
(0.0234)\end{array}$ & $\begin{array}{c}0.0699 * * * \\
(0.0223)\end{array}$ \\
\hline firmaccMENA & & $\begin{array}{c}-0.0911 * * * \\
(0.0220)\end{array}$ \\
\hline Observations & 52 & 52 \\
\hline Countries & 18 & 18 \\
\hline $\begin{array}{l}\text { Chi-Sq. Stat. } \\
\text { Sargan P-value }\end{array}$ & $\begin{array}{r}27.33 \\
{[0.99]}\end{array}$ & $\begin{array}{c}19.17 \\
{[0.99]}\end{array}$ \\
\hline
\end{tabular}


Table 20: MENA Total Effects of

Firm's Access to Finance

\begin{tabular}{|l|l|}
\hline Regressors & Total Effect \\
\hline
\end{tabular}

\begin{tabular}{|c|c|}
\hline finv & $\begin{array}{c}0.03 \\
(0.03)\end{array}$ \\
\hline fwork & -0.02 \\
& $(0.03)$ \\
\hline$f c$ & $-0.08^{*}$ \\
& $(0.05)$ \\
\hline firmacc & -0.002 \\
& $(0.004)$ \\
\hline
\end{tabular}


Table 21: Firm's Access to Finance \& Economic Growth With Governance Dependent variable: Economic Growth

Estimation Method: Dynamic Panel System GMM

\begin{tabular}{|c|c|c|c|c|}
\hline Regressors & $(1)$ & $(2)$ & (3) & (4) \\
\hline$L . g r$ & $\begin{array}{l}-0.115 \\
(0.219)\end{array}$ & $\begin{array}{c}-0.186 \\
(0.276)\end{array}$ & $\begin{array}{c}-0.184 \\
(0.129)\end{array}$ & $\begin{array}{c}-0.150 \\
(0.262)\end{array}$ \\
\hline $\inf$ & $\begin{array}{c}-0.150 * * * \\
(0.0347)\end{array}$ & $\begin{array}{c}-0.156^{* * *} * \\
(0.0447)\end{array}$ & $\begin{array}{c}-0.166 * * * \\
(0.0413)\end{array}$ & $\begin{array}{c}-0.144 * * * \\
(0.0385)\end{array}$ \\
\hline$i n v$ & $\begin{array}{c}0.101 * * * \\
(0.0231)\end{array}$ & $\begin{array}{c}0.107 * * * \\
(0.0309)\end{array}$ & $\begin{array}{c}0.119 * * * \\
(0.0357)\end{array}$ & $\begin{array}{c}0.0980 * * * \\
(0.0261)\end{array}$ \\
\hline govexp & $\begin{array}{l}-0.168 \\
(0.136)\end{array}$ & $\begin{array}{c}-0.142 \\
(0.0904)\end{array}$ & $\begin{array}{l}0.0168 \\
(0.112)\end{array}$ & $\begin{array}{l}-0.153 \\
(0.105)\end{array}$ \\
\hline$o p$ & $\begin{array}{c}0.0359 * * \\
(0.0180)\end{array}$ & $\begin{array}{c}0.0376^{* * *} \\
(0.0139)\end{array}$ & $\begin{array}{c}0.0587 * * * \\
(0.0209)\end{array}$ & $\begin{array}{c}0.0330^{* *} \\
(0.0155)\end{array}$ \\
\hline popgr & $\begin{array}{c}0.700 * * \\
(0.334)\end{array}$ & $\begin{array}{l}0.834^{*} \\
(0.483)\end{array}$ & $\begin{array}{l}1.733^{*} \\
(0.901)\end{array}$ & $\begin{array}{c}0.710 \\
(0.476)\end{array}$ \\
\hline finv & $\begin{array}{c}0.149 * * \\
(0.0685)\end{array}$ & & & \\
\hline finvgovMENA & $\begin{array}{c}-0.0785^{* * *} * \\
(0.0189)\end{array}$ & & & \\
\hline fwork & & $\begin{array}{c}0.0938 * * \\
(0.0376)\end{array}$ & & \\
\hline fworkgovMENA & & $\begin{array}{c}0.0469 \\
(0.0527)\end{array}$ & & \\
\hline$f_{c}$ & & & $\begin{array}{l}-0.0230 \\
(0.0807)\end{array}$ & \\
\hline fcgovMENA & & & $\begin{array}{l}0.125 * * \\
(0.0485)\end{array}$ & \\
\hline firmacc & & & & $\begin{array}{l}0.121 * * \\
(0.0471)\end{array}$ \\
\hline firmaccgovMENA & & & & $\begin{array}{c}-0.006 \\
(0.0378)\end{array}$ \\
\hline Observations & 30 & 28 & 30 & 28 \\
\hline Countries & 10 & 10 & 10 & 10 \\
\hline
\end{tabular}


Chi-Sq. Stat.

$\begin{array}{lcccc}\text { Sargan P-value } & {[0.97]} & {[0.34]} & {[0.41]} & {[0.42]}\end{array}$

4.31

[0.97]

15.35

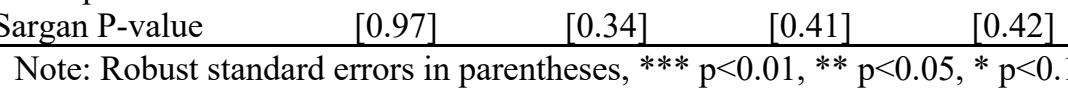

14.55

15.40

Table 22: MENA Total Effects of Firm's

Access to Finance with Governance

\begin{tabular}{|c|c|}
\hline Regressors & Total Effect \\
\hline
\end{tabular}

\begin{tabular}{|c|c|}
\hline Regressors & Total Effect \\
\hline finv ${ }^{*}$ gov & 0.0701 \\
& $(0.061)$ \\
\hline fwork ${ }^{*}$ gov & $0.141^{*}$ \\
& $(0.075)$ \\
\hline fc $^{*}$ gov & 0.102 \\
& $(0.109)$ \\
\hline firmacc ${ }^{*}$ gov & $0.115^{*}$ \\
& $(0.0069)$ \\
\hline
\end{tabular}

